\title{
ANALYSIS OF VACANT AND ABANDONED PROPERTIES IN THE CITY OF TORONTO
}

\author{
by \\ Vanessa Fletcher \\ BURP1, Ryerson University, 2008 \\ BA, University of Waterloo, 2005 \\ A Major Research Paper \\ presented to Ryerson University \\ in partial fulfillment of the requirements for the degree of \\ Master of Planning \\ in \\ Urban Development
}

Toronto, Ontario, Canada, 2014

(C) Vanessa Fletcher 2014 


\section{Author's Declaration}

I hereby declare that I am the sole author of this MRP. This is a true copy of the MRP, including any required final revisions.

I authorize Ryerson University to lend this MRP to other institutions or individuals for the purpose of scholarly research

I further authorize Ryerson University to reproduce this MRP by photocopying or by other means, in total or in part, at the request of other institutions or individuals for the purpose of scholarly research.

I understand that my MRP may be made electronically available to the public. 


\title{
ANALYSIS OF VACANT AND ABANDONED PROPERTIES IN THE CITY OF TORONTO
}

(C) Vanessa Fletcher 2014

\author{
Master of Planning \\ in \\ Urban Development \\ Ryerson University
}

\begin{abstract}
The city of Toronto is in the midst of unprecedented development fuelled by lowinterest mortgage rates, foreign investment and staggering commute times. Despite this, a small percentage of properties remain vacant or abandoned in Toronto. This paper identifies the types of properties that are vacant and abandoned, assesses the property stock for degree of decay and re-examines the appropriateness of the classification of 'vacant' and 'abandoned'.

This research indicates that vacant buildings in Toronto transition to abandonment for reasons that may be different from American cities. Vacancy in Toronto may be more affected by lengthy planning approvals, development financing and issues of site acquisition, more than urban decay or blight.

The research further indicates that most vacant and abandoned buildings in Toronto are residential, commercial vacancy is transient by nature and industrial abandonment is found mostly along existing railway corridors.
\end{abstract}

\section{Key words:}

vacant properties; abandoned properties; abandoned; Toronto 


\section{Acknowledgements}

Thank you to Dr. Chris De Sousa for his expertise and encouragement in the completion of this research.

I would also like to thank the City of Toronto, and in particular, Tracey Cook for her steadfast support of my education and Carleton Grant for his insights into the project. 


\section{Table of Contents}

$\begin{array}{ll}\text { Introduction } & 1\end{array}$

City of Toronto Context 3

Defining Vacancy 5

Vacant properties $\quad 5$

Abandoned properties $\quad 5$

Vacant lots 6

Mothballed Sites $\quad 6$

Brownfields 6

$\begin{array}{ll}\text { Current Regulation of Vacant Properties } & 7\end{array}$

Literature Review 9

Housing Demolitions $\quad 12$

Strategies for Reuse $\quad 12$

Method 14

Data $\quad 15$

Site Visits 16

Limitations $\quad 17$

$\begin{array}{ll}\text { Findings } & 18\end{array}$

Residential Properties $\quad 21$

Abandoned Residential (site visit \#1) 24

Abandoned Residential (site visit \#3)

Vacant Residential (site visit \#5) 26

Abandoned Residential (site visit \#8) 26

Abandoned Residential (site visit \#9)

Vacant Residential (site visit \#10) 28

Commercial Properties $\quad 29$

Abandoned Commercial (site visit \#13) 31

Vacant Commercial (site visit \#15) 31

Vacant Commercial (site visit \#18) 32

Industrial Properties $\quad 33$

Abandoned Industrial (site visit \#21)

Vacant Industrial (site visit \#22)

Vacant Industrial (site visit \#23) 36

Vacant Industrial (site visit \#24) 36

Results and Discussion $\quad 37$

Revisiting the definitions of Vacancy and Abandonment 39

Reasons for Vacancy $\quad 42$

Cost of Vacancy $\quad 43$

$\begin{array}{ll}\text { Appendix A } & 46\end{array}$

$\begin{array}{ll}\text { References } & 48\end{array}$ 


\section{List of Figures}

Figure 1: Three broad zones of Toronto: downtown core, outer downtown and inner-suburbs

Figure 2: Map of all Vacant and Abandoned Properties in Toronto

Figure 3: Vacant and Abandoned Properties in Toronto (2013)

Figure 4: Vacant and Abandoned Properties Compared (2013)

Figure 5: Vacant and Abandoned Residential Properties in Toronto

Figure 6: Summary of Residential site visits

Figure 7: Vacant and Abandoned Commercial Properties in Toronto

Figure 8: Summary of commercial site visits

Figure 9: Vacant and Abandoned Industrial Properties in Toronto

Figure 10: Summary of industrial site visits

Figure 11: Vacancy and abandonment as distinct categories

Figure 12: Vacancy as a process 


\section{Introduction}

Since the economic downturn in 2008, many American cities have suffered a compounded issue of vacant and abandoned buildings. Words like 'blight' or 'decay' haunt these cities, especially in their downtown core. Places like Buffalo, Pittsburgh and Detroit bring powerful images of urban decay and neighbourhood breakdown to mind.

Canadian cities are not largely associated with this type of blight. With strong real estate prices and a healthy economy, vacant and abandoned buildings are not at the forefront of local urban planners minds. But in fact, Toronto does suffer from vacant and abandoned properties that affect communities (personal communication with Tracey Cook, Executive Director, Municipal Licensing \& Standards, March 15, 2014). Outdated property tax rebates, a lack of understanding of the issue, and the lack of a comprehensive strategy to mitigate these impacts have inadvertently permitted, and even subsidized, vacant and abandoned properties in Toronto.

It is argued that vacant and abandoned properties negatively impact communities (City of Toronto, 2014; Wachsmuth, 2008; Branas et. al., 2012). Although, others recognize vacant properties, particularly commercial properties, as underutilized assets that can be leveraged to create jobs, foster economic growth and be repurposed through other creative solutions that can improve communities (City of Toronto, 2014; Tappendorf, 2011). As research shows that vacant property is an indicator of urban change, and that vacant properties may require government interventions to encourage re-use (Pegano \& Bowman, 2000; Hirokawa \& Gonzalez, 2010), there is an outstanding need to conduct research on vacant and abandoned properties in Toronto.

This paper analyzes the quantity and distribution of vacant and abandoned properties in Toronto and further analyzes this data by use (residential, industrial or commercial) and identifies patterns that can potentially explain how and why vacant and abandoned properties happen in Toronto. 
The research questions explored through this paper are:

1. How many vacant and abandoned properties are there in Toronto?

2. Where are these properties located? How are they dispersed?

3. What does vacancy and abandonment look like in Toronto?

4. Why do buildings become vacant or abandoned?

5. What are the existing regulatory tools to address vacant properties?

The research for this paper was conducted over 4 months in the summer of 2014. A broad review of relevant literature from an American and European context was conducted, which subsequently informed the research questions. Data was collected from the City of Toronto on the number of affected properties. This data was classified and charted to help distinguish patterns. Addresses were geocoded onto a map, where clusters and patterns were identified. Twenty-five site visits were conducted to inform the analysis and identify the state of vacancy.

This paper analyzes the quantity, geographic distribution and former use of vacant and abandoned buildings in Toronto. The research looks at the differences between vacant and abandoned properties, analyzes the distribution of these properties and begins to create typologies of vacant and abandoned properties in Toronto. The research illuminates the state of Toronto's vacant properties and lays the foundation for understanding vacancy in Toronto in an effort to inform future policies and bylaws that may help to mitigate these issues.

This paper begins with an overview of Toronto's market and regulatory context, followed by a literature review of contemporary American and European research, then overview of methods and finally the results and discussion section. 


\section{City of Toronto Context}

Toronto is Canada's largest city and is its economic engine, generating \$144 Billion in $2011,11 \%$ of the national GDP (Toronto Financial Services of Toronto, 2011). It is located with the Greater Toronto Area (GTA) defined as the central city of Toronto, and the four regional municipalities that surround it: Durham, Halton, Peel, and York. The population of the GTA is over 6 million. It is located in southern Ontario, just north west from New York state, USA. With a core population of over 2.8 million residents, it is 4 times larger than Vancouver and almost twice as big as Montreal, Canada's other two largest urban centres, and is home to a diverse population.

Toronto has seen unprecedented amounts of development in the last decade. In fact, in 2013 Toronto had more cranes in the sky then New York City, Chicago or Shanghai (Emporis, 2014). This enormous new development has been reshaping the city to create high density and urban neighbourhoods - where residents are trading square footage for downtown living styles. This development has been mostly localized to the downtown core and has been dominated by condominium built form. The condo market in Toronto has been fuelled by several factors, including: unprecedented low interest rates that have promoted homeownership for many young professionals, relatively low municipal development fees, undeveloped land in the downtown core, congestion and significant foreign investment that have cumulatively funded, in essence, a secondary rental housing market.

In addition to this unprecedented development (increase in supply), housing prices in Toronto have increased 4 times more than the cost of living index (City of Toronto, 2014). This means that housing affordability remains a significant challenge for residents of Toronto, but that the housing market is red hot.

These factors lead to increased demand for land in Toronto. The city has seen over 163,000 residential units, and 4.41 million square meters of non-residential GFA (gross floor area) proposed between 2009 and 2013 (City of Toronto, 2014). Of the proposed residential developments, $86 \%$ is in areas targeted for growth in the city's Official Plan, 
while $80 \%$ of all new office space under construction is located downtown (City of Toronto, 2014).

A redevelopment application is filed in Toronto when a developer proposes to change the zoning for a certain parcel of land. A significant number of new, high density condos have been built on existing at-grade parking lots and former industrial lands, where these previous uses have become less of a priority in Toronto. Developers may also try to amass a series of properties of existing detached or semi-detached housing and apply for a rezoning for increased density that can lead to significant return on investment, while intensifying Toronto's urban fabric.

Compared to US industrial cities that are facing unprecedented population decline and resultant vacancy and abandonment issues, Toronto's vacancy and abandonment issues follow a different trajectory. In fact, Toronto's vacant and abandoned at-grade properties only represent $0.1 \%$ and compared to Detroit (28\%) Flint (39\%) and Pittsburgh (15\%) (Hackworth, 2013).

In growing cities, like Toronto, surplus and underutilized land is a valuable asset that needs to be utilized (De Sousa, 2006; Schwarz, 2011). Increasing Toronto's density through redeveloping underutilized lands means more compact growth that helps limit urban sprawl. Higher density neighbourhoods increase property taxes that help fund sustainable modes of transportation like transit, cycling and walking and subsequently help mitigate congestion. Promoting redevelopment of underutilized lands, like vacant and abandoned properties, supports sustainable growth. 


\section{Defining Vacancy}

The role in regulating vacant and abandoned buildings has led to bylaws and ordinances in most cities in North America (Pagano \& Bowman, 2000). But within the literature it becomes evident that there is much disagreement on the terms that define vacant and abandoned buildings. The wide range of definitions in the literature indicates that terms like 'vacancy', 'abandoned' and 'derelict' are hard to define, and that they should be defined within their own municipal context (Wachsmuth, 2008; Pagano \& Bowman, 2000; Davis 2012; Morckel, 2014).

In different cities, and throughout the literature, definitions of vacancy and abandoned properties differ. It could be the nebulous nature of abandoned properties that perpetuate the discrepancies in definitions. For the purposes of the paper, the following definitions are used when referring to types of properties.

\section{Vacant properties}

The definition of vacant properties by the Toronto Fire Services is a "property that is not currently occupied but well-maintained (ie - no broken windows or signs of structural degradation) and locked". This definition includes the 'use' of the property, broadly categorized into: vacant residential, vacant commercial and vacant industrial. These categories have been assigned based on the previous 'use' and do not necessarily represent the existing zoning on the site.

\section{Abandoned properties}

The definition of abandoned properties by the Toronto Fire Services is a "building that has been boarded-up and may have compromised structural integrity". This definition has includes the 'use' of the property, broadly categorized into: abandoned residential, abandoned commercial and abandoned industrial. These categories have been assigned based on the previous 'use' and do not necessarily represent the existing zoning on the site. 
Other related types of properties are defined below.

\section{Vacant lots}

Defined as parcels of land that do not have a structure on it and may be underutilized, or contaminated (Home, 1983).

\section{Mothballed Sites}

Sites that are vacant and secured (windows boarded/fenced) which protects the site from falling into disrepair, often while developers acquire additional land and/or secure planning approvals (Schwarz, 2011).

\section{Brownfields}

There are several definitions of brownfields within the literature. Most describe brownfields as abandoned or underused land, while others specify that brownfields are commercial/industrial lands. A final distinction is the requirement that lands are either known to be contaminated or suspected to be contaminated (Environmental Protection Agency, 2014) 


\section{Current Regulation of Vacant Properties}

In 2006, the province released the Growth Plan for the Greater Golden Horseshoe. This is a 25-year plan aimed at directing growth to urban centres that will curb sprawl and protect green spaces and farmland for future generations (Places to Grow, 2006). A growth plan for the region provides an overarching rationale for reusing vacant and underutilized land versus developing greenfields.

In Toronto, the regulation of vacant and abandoned properties lays mostly with the municipality. Chapter 632 of the City of Toronto Act (COTA) gives the city authority to maintain a certain level of standards in regard to vacant and/or hazardous properties. City staff have broad powers through COTA to maintain standards through ordering that fences be erected and windows be secured through boarding. Further, the city can lay offences and penalties if owners do not comply with standards, up to $\$ 100,000$.

Many times, owners of abandoned or vacant properties do not comply with city orders and are difficult to contact (Personal communication, Tracey Cook, May 27, 2014). In these instances, staff can bring the property up to code by constructing fencing, securing buildings and maintaining yards. The cost of this work is then applied to the property taxes for the address.

Commercial and industrial vacant properties in Toronto are able to apply for a rebate on a part of their property taxes. This is called the Vacant Commercial and Industrial Tax Program (VCITP) and is mandated by the province. This was a program that was instituted by the Province in order to help local business owners negate financial impacts during periods of vacancy. Recently, the City of Toronto was directed to review this program for effectiveness, since vacant commercial/industrial properties have negative impacts on communities and are currently subsidized through the property tax base. The VCITP property tax rebate program in 2012 and 2013 is expected to exceed $\$ 40$ million in lost revenue for the City of Toronto (City of Toronto, 2014). 
Given the current fiscal situation of governments at all levels, there is considerable attention being paid to revenue sources, including the property tax base. Rebates that reward property owners for maintaining vacant or abandoned properties, particularly given the robust property market, do little for the community and city coffers and as such, will be undergoing review.

Ultimately, owners of vacant and abandoned land in Toronto are responsible to maintain their land, but Toronto employs some tools to ensure that land left vacant and abandoned is utilized better and/or repurposed in a way that can positively impact the community (City of Toronto, 2014). Some examples of these tools include: Toronto's Official Plan which manages growth and directs intensification and Community Improvement Plans (CIP) which focus on areas in need of improvement or rehabilitation. Toronto's Official Plan is the vision for where and how Toronto will grow to the year 2031. It plans for this growth through transit, land use and environmental lenses, and is reviewed and amended on an ongoing basis. Community Improvement Plans are a tool outlined in the Planning Act that allows cities to improve the use, reuse and restoration of lands, buildings and infrastructure. 


\section{Literature Review}

Research shows that vacant property is an indicator of urban change, and may require government intervention to encourage re-use (Katyoka \& Wyatt, 2008). Cities inevitably grow, shrink and change over the course of time and this inevitably impacts the way we plan for cities (Schwarz, 2011). Redevelopment of urban areas can create benefits for cities; these benefits include expanding the tax base, job creation and improved urban fabric (De Sousa, 2001).

It is argued that vacant properties negatively impact communities (City of Toronto, 2014; Wachsmuth, 2008). Although, others recognize vacant properties as underutilized assets that can be leveraged to create jobs, foster economic growth and be repurposed through other creative solutions that can improve communities.

There is need for a more comprehensive analysis and understanding of vacant and abandoned properties in Toronto, as there is currently no central list that identifies these properties. Wachsmuth (2008) reports that despite Toronto's thriving real estate market, vacant residential buildings, in particular, Toronto's aging private rental housing stock present significant vacancy issues.

The city of Toronto has less than $0.1 \%$ of its properties deemed vacant or abandoned through visual inspection of properties at grade. Although this is an extremely small percentage, the literature speaks to the impacts these properties can have on communities.

Despite the perception amongst policy makers, there is consensus in the literature that vacancy and abandonment is a process, not a static classification (Wachsmuth, 2008; Katyoka \& Wyatt, 2008). This is in contrast to the belief that vacancy and abandonment is a binary state, i.e. - a building is either vacant, or not. The reason this becomes convoluted in the literature is because words like vacancy, abandoned and derelict are defined in complex ways, which indicates that abandonment starts in many ways. Some properties are vacant for short periods of time. This can be caused by reasonable tenancy transitions (i.e., when it takes a landlord a number of months to find a suitable tenant), or 
possibly from when owners want to improve the property through renovations, or while the property is for sale. This type of vacancy is at a very 'low risk' for becoming abandoned since the vacancy is due to a specific reason that can be resolved. The literature identifies that vacancy is also affected by the economy and other changes to the urban environment, where issues of abandonment can follow, but these factors are more permanent influences (Wachsmuth, 2008; Katyoka \& Wyatt, 2008). This impresses the importance of a pragmatic assessment of the problem within the context and that recommendations should be grounded in an understanding of the fluid nature of 'vacancy'.

The perception and treatment of the issues varies in the US and European literature. In America, many cities have built housing and retail space that is too abundant for the city's foreseeable future (Schwarz, 2011). For example, in Cleveland, Ohio, 7\% of the city's land mass is deemed vacant (Schwarz, 2011). This over supply of built form puts a downward pressure on real estate values, most often hitting downtown and inner ring suburbs the hardest (Schwarz, 2011). As well, since 2008, the US has experienced unprecedented foreclosures, due to subprime mortgages and subsequent recession, where Canada has been less affected by this type of vacancy (Tappendorf \& Denzin, 2011, 2012). This means there are several approaches that may work in an American context, but would need to be thoroughly reviewed for its appropriateness for a Canadian context (Tappendorf \& Denzin, 2011; Davis 2012).

In the UK however, there have been several studies on the impacts of vacant and abandoned commercial and industrial properties due to deindustrialization. This has emerged from the changing industrial nature of industry-based employment in the UK, in particular in the north of England (Katyoka \& Wyatt, 2008). This research may prove more relevant and can be leveraged when trying to understand Toronto's vacant and abandoned commercial and industrial lands.

The bulk of the literature attributes vacancy and abandonment to deindustrialization that has led to global changes in manufacturing and goods production and subsequent large 
scale population decline (Hackworth, 2013). In the US, many cities are suffering from such population decline. Industrial cities located in the 'rust belt', once built on the booming automotive sector in the 50s and 60s, have been particularly impacted by population decline. This type of industrial decline has been linked to decay of surrounding neighbourhoods, where the effect of blight can spread (Hackworth, 2013). Pittsburgh, Detroit and Buffalo bring stark images of vacant properties and abandonment to mind (Schwarz, 201; Hackworth, 2013).

As local governments have seen a correlation between the characteristics of abandoned properties, like unkempt yards, garbage accumulation, unsightly and dangerous structures, with neighbourhood blight, local governments have enacted their powers to regulate vacant buildings to help mitigate these effects (Hirokawa \& Gonzalez, 2010). Evidence that links vacant and abandoned buildings to neighbourhood decline is important in understanding the impacts of these types of properties.

The impact that vacant and abandoned buildings have on surrounding property value is a primary concern outlined in the literature (Han, 2014). An economic principle can be applied to the issues of vacancy and abandonment. As value is derived from scarcity, then an over abundance of properties can lead to a destabilization of real estate markets (Schwarz, 2011). If the number of vacant and abandoned properties increase, communities are at risk of property value decline, which then impacts the city's ability to collect property taxes, which are typically based on property value. Abandoned properties also attract pests, vandalism, trespassing and other indicators of urban decay which can lead to devalued property value for adjacent properties.

To add to the issue of declining property values, vacant houses also often present dangers to public safety (Branas, 2012; Schwarz, 2011). Vacant properties can be used to indicate physical disorder of a community and can attract criminal activity (Branas, 2012). In the US, these types of properties can symbolize a weak community that is akin to the 'broken window' theory (Branas, 2012). Branas (2012) found that vacant properties in Philadelphia County were significantly associated with aggravated assaults (in particular 
gun assaults). This was found even after the researchers had controlled for demographics and socioeconomic characteristics of neighbourhoods, and they further found that vacant properties impacted communities the most, beyond other significant measures of community disadvantage (Branas, 2012). Although we must be cautious in inferring causation and applying generalities from these types of finding, these findings add to a body of literature that supports the theory that vacant and abandoned properties have negative impacts to communities.

Through the literature, some examples of tools to address vacancy and abandonment became apparent. Finding other uses for the land, and possibly housing demolitions, were two broad approaches identified as ways to address these types of properties.

\section{Housing Demolitions}

The public often wants abandoned houses demolished and these programs are seen throughout the US. In Cleveland, 1,000 houses are demolished each year due to abandonment (Schwarz, 2011).But the literature is divided on the positive impacts these types of programs have on neighbouring property values by disrupting community cohesiveness and the potential loss of historic architecture (Schwarz, 2011).

\section{Strategies for Reuse}

If cities are able to gain the authority to tear vacant and abandoned properties down, there is the inevitable question of, "what do you repurpose the site for?". Vacant lots may have some of the same community impacts as vacant houses. Sites do not become naturalized instantly, and in some instances, these types of spaces continue to look unkempt and cause further nuisance than the original vacant house. In Flint, Michigan, vacant lots must have a strip of grass at the front lot line that is easy to maintain with a lawn mower, then indigenous plant species are planted to naturalize the environment behind.

Strategies that encourage adaptive reuse can restore real estate values, improve urban ecosystems and public health while growing the economy (Schwarz, 2011; Han, 2014). Cities can repurpose vacant and abandoned lands for community gardens, parks or storm 
water management. By doing this, abandoned and vacant properties are able to be repurposed as community assets.

Cities can also be strategic in repurposing - if the city is able to amass several vacant properties together, the amalgamated vacant property can be repurposed in a different way, such as: parks, urban agriculture, solar/wind/geothermal power, community space or small business incubators. It should be noted that many of the approaches of reuse and demolition, can face political barriers as these tools can impact the property tax base. For example, turning land into park space exempts land from property taxes that can lead to reduced revenue for cities.

Through the literature, it becomes apparent that there are other tools that may work in a specific context, but would need to be thoroughly reviewed for its appropriateness for a Canadian context (Tappendorf \& Denzin, 2011; Davis 2012). Examples of these include: land banking, tax increment financing (TIFs) and Vacant Property Registration Ordinances (Tappendorf \& Denzin, 2011; Davis 2012). 


\section{Method}

In order to gather information to address the research question 1 and 2 (how many vacant and abandoned properties are there? And where are they located?), requests were made to the City of Toronto to provide a list of affected properties. It then became apparent that the City of Toronto does not formally maintain a list of vacant and abandoned properties in Toronto. This is partially due to the fluid nature of vacancy within properties, but is also a result of the private nature of vacancy (ie - there is no law that owners must notify the government when they leave their properties vacant).

Although the City of Toronto does not have any formal system for tracking vacant and abandoned properties, most recently, Toronto's fire department has been surveying the city for vacant and/or abandoned properties through foot surveys and maintaining a list of addresses. There are other non-direct ways of measuring vacancy in Toronto as there are several databases that house this type of data. Properties that have been left vacant and/or abandoned and have subsequently attracted considerable public concern, have been flagged by the City and often have multiple work orders placed to ensure that the property is brought up to minimum property standards. As well, properties that are in property taxes arrears would be flagged on a list. Although these types of databases are rich with information, they are both disaggregate and incomplete. An example of this, is that although owners of abandoned properties may not pay their property taxes, not all properties listed would be considered abandoned. And conversely, not all abandoned properties are in tax arrears. This presents issues when trying to assess the magnitude and pattern of vacancy and abandonment.

For this paper, data was collected through Toronto Fire Services. By maintaining this list, when firefighters arrive at a property they are able to assess if people are expected to be inside the building, or in the case of abandoned buildings, the structural integrity of the building. This list was originally generated by City Planning's database on a word search for the terms 'vacant' and 'abandoned'. This crude data search revealed thousands of addresses that at one time had these terms listed in the notes. Toronto Fire Service took this list and divided it by each fire hall and assigned each fire hall the duty of surveying 
each neighbourhood to verify or strike each address from the list. Through this process, the list was shortened to 835 properties. Although this is the most accurate list that could be utilized for this research, there are several limitations: firstly, the list is only current to 2013, secondly, it may be missing some unidentified addresses, and lastly does not identify vacant apartment or condominium units, as they cannot be surveyed from street level.

The list of vacant and abandoned properties obtained by Fire Services includes street addresses and 2013 observed uses. This varies in some cases from the zoning for the site, although this paper consistently uses the 'use' as categorized by Fire Services. Fire Services also identified the property as either 'vacant' or 'abandoned' and this designation was maintained for this paper.

\section{Data}

For spatial analysis, the data was separated by these categories and uses as follows:

1. Vacant residential

2. Vacant commercial

3. Vacant industrial

4. Abandoned residential

5. Abandoned commercial

6. Abandoned industrial

The data was plotted on several maps and analyzed for patterns or clusters. Sites were divided into 3 zones in Toronto. These zones are delineated in Figure 1 and represent broadly the downtown core of Toronto, the outer downtown area and the inner-suburbs of Toronto. Specific attention was paid to railway corridors (previous industrial zones), waterfront (previous industrial and commercial areas in Toronto), downtown/inner suburban context and low-income neighbourhoods. Based on the analysis of the distribution and frequency of the properties as described above, site visits were planned. 
Figure 1: Three broad zones of Toronto: downtown core, outer downtown and inner-suburbs

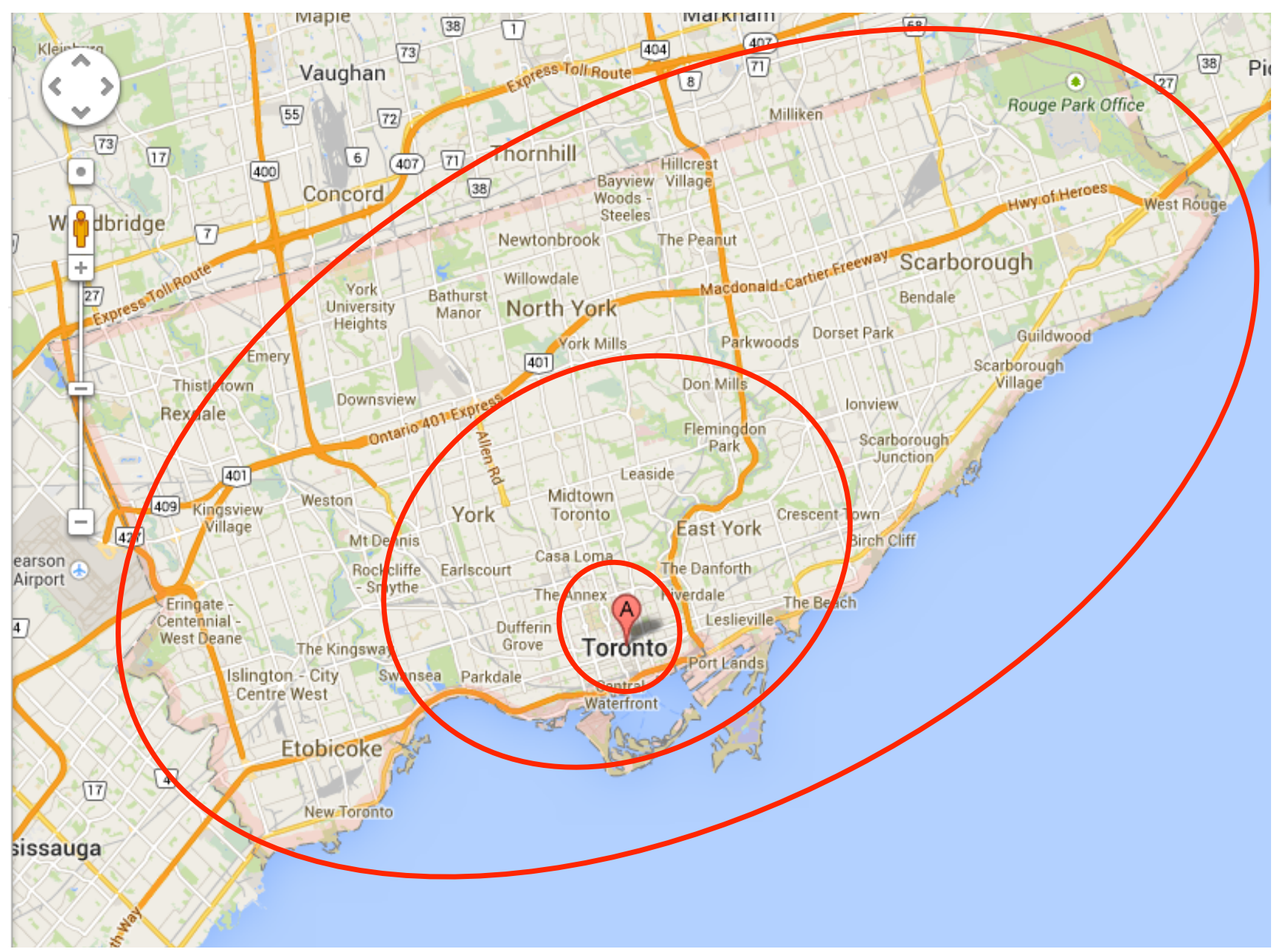

Map source: https://maps.google.ca/

\section{Site Visits}

Three types of site visits were conducted based on the visual analysis of the data during the mapping phase: Residential Site Clusters; Railway Corridor Industrial/Commercial Sites; and Commercial Site Clusters. Of these three types of site visits, sites were selected randomly, with attention paid to the need to visit both vacant and abandoned properties, and an endeavour to visit multiple neighbourhoods in Toronto.

$3 \%$ of vacant and abandoned properties were surveyed for this research; 25 site visits were conducted in July 2014. There was a mix of residential, commercial and industrial 
vacant and abandoned sites. Effort was made to visit sites in a wide array of neighbourhoods, throughout the city. At each site visit, photos of specific addresses were taken. A 'Visual Assessment Chart' (VAC) was completed for each site (Appendix A). The VAC documents a description of the features of the property, notes neighbourhood qualities (including neighbouring properties) and assesses the state of vacancy and abandonment. Both the photos and VACs were utilized in the assessment and analysis of vacant properties.

\section{Limitations}

This method is limited by a lack of time and budget that would have allowed more comprehensive data analysis and fulsome site visits. If expertise and time were available, this method could be improved by completing a statistical analysis of the addresses to identify statistically significant clusters. As well, if there was more time, additional site visits would increase the understanding of vacant and abandoned buildings in Toronto. 


\section{Findings}

As of 2013, there were 835 vacant or abandoned properties in the City of Toronto. These properties are dispersed across the city's geographic landscape. There is no ward in the City of Toronto that is not affected by vacant and abandoned properties.

Categories (vacant or abandoned) are delineated by colour. Vacant properties are assigned the colour blue for all mapping purposes, while abandoned properties are assigned the colour green. While 'uses' (residential, commercial and industrial) are delineated by shapes: residential with houses, commercial with circles and industrial with squares.

Figure 2: Map of all Vacant and Abandoned Properties in Toronto

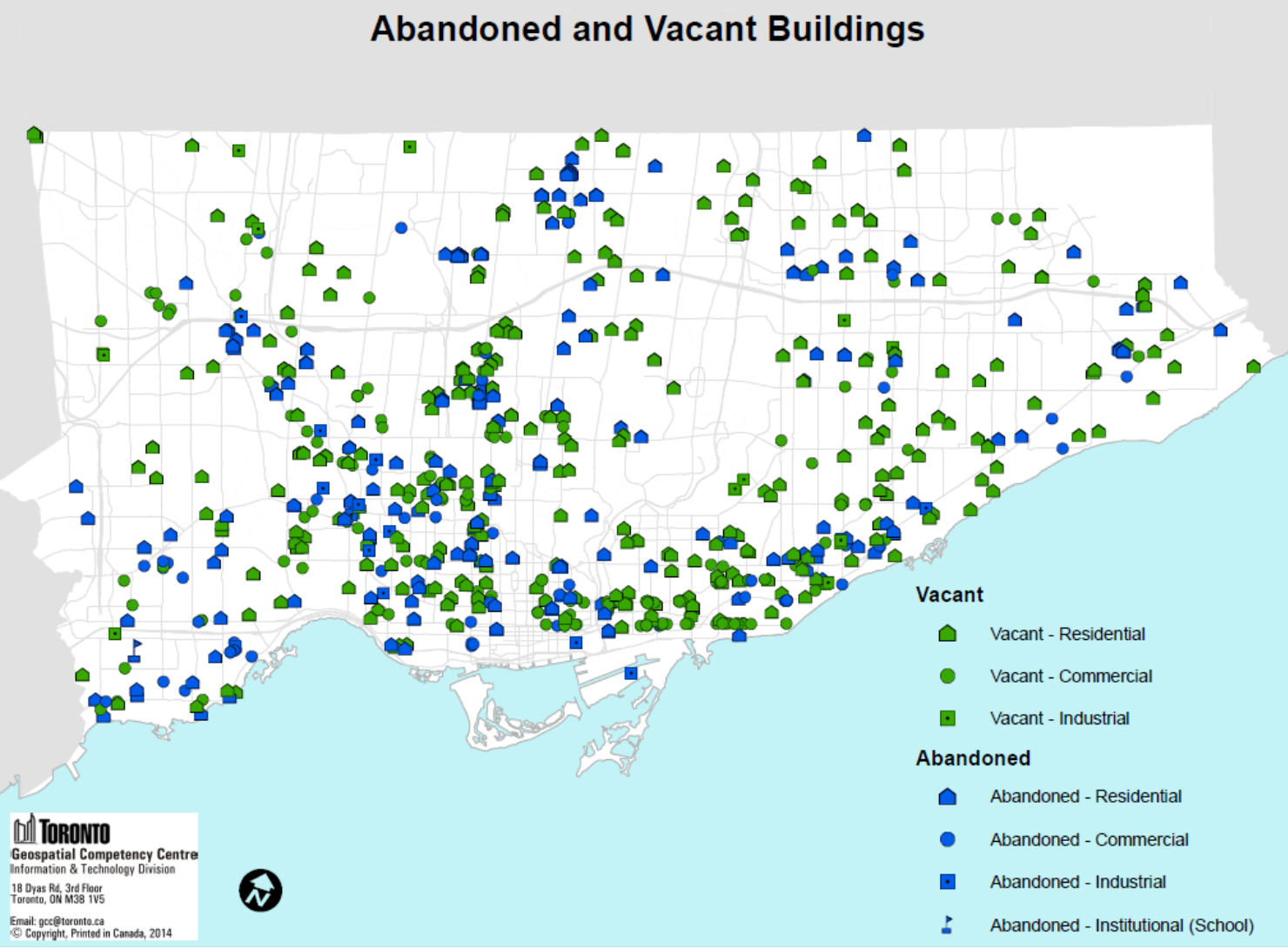


There appears to be some clustering of sites located along Weston Rd. and the railway line from the 401 south to the neighbourhood of Parkdale, along the downtown core and east towards Scarborough.

Out of the 835 properties identified, $41 \%$ were classified as 'abandoned', while $59 \%$ were classified 'vacant'. Having more properties classified as 'vacant', than 'abandoned', may be significant since vacant properties may have less community impacts than abandoned properties.

Figure 3: Vacant and Abandoned Properties in Toronto (2013)

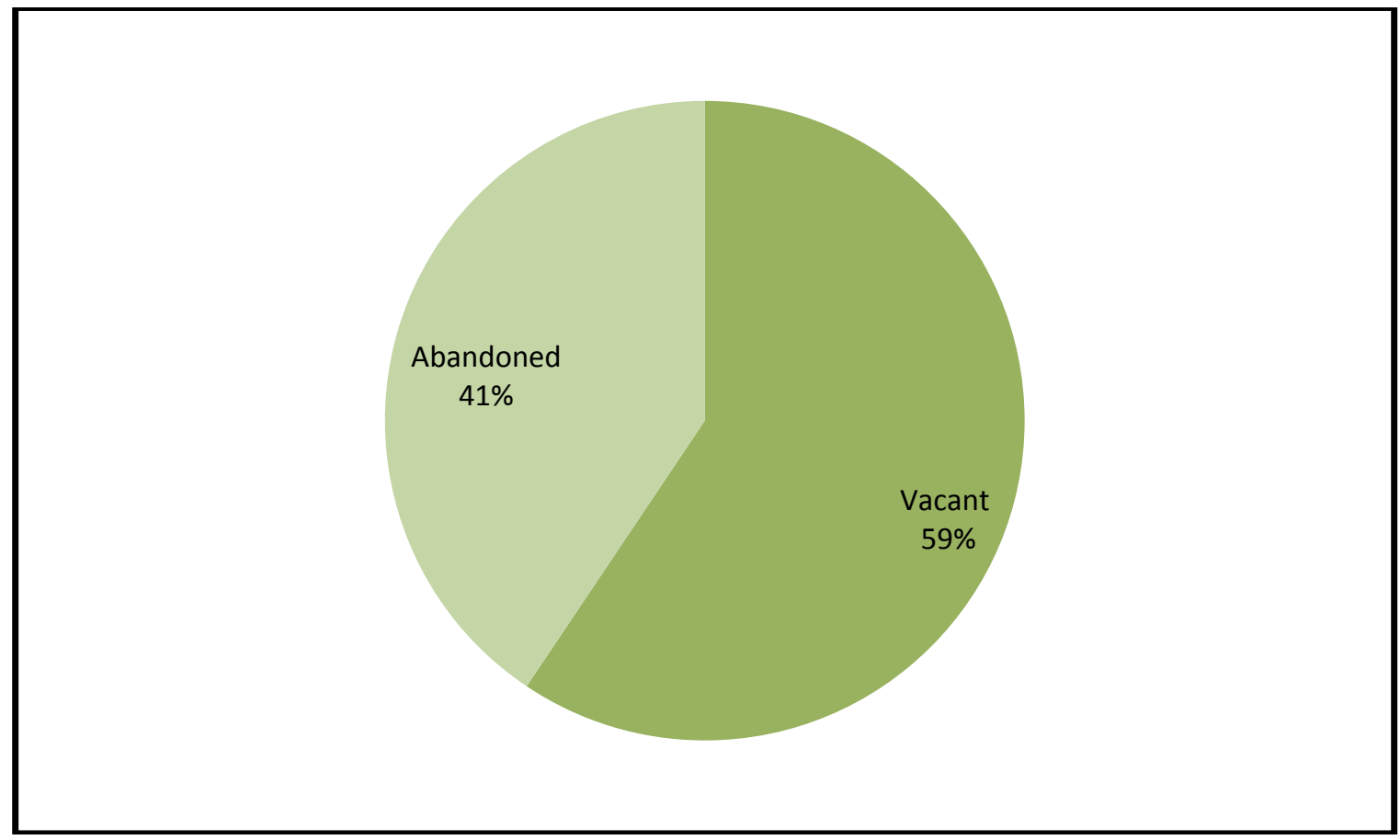

For both vacant and abandoned buildings, residential properties were the most likely to be vacant or abandoned. Of vacant properties, $57 \%$ were residential, $40 \%$ commercial and 3\% industrial. Most notably, of abandoned properties, $71 \%$ were residential. Other abandoned properties were as follows: $22 \%$ commercial and $7 \%$ industrial. This means that in Toronto, vacancy and abandonment is most often found in the residential housing stock. 
Commercial uses are more often vacant than abandoned. This may be due to the fluid nature of commercial vacancy, especially found in retail commercial, where entrepreneurs and small businesses find themselves opening and closing more frequently than larger companies. Toronto has a small number of vacant and abandoned industrial sites. Of these sites, most are abandoned and not suitable to be easily repurposed. This is in contrast to retail vacancy that is more easily repurposed.

\section{Figure 4: Vacant and Abandoned Properties Compared (2013)}

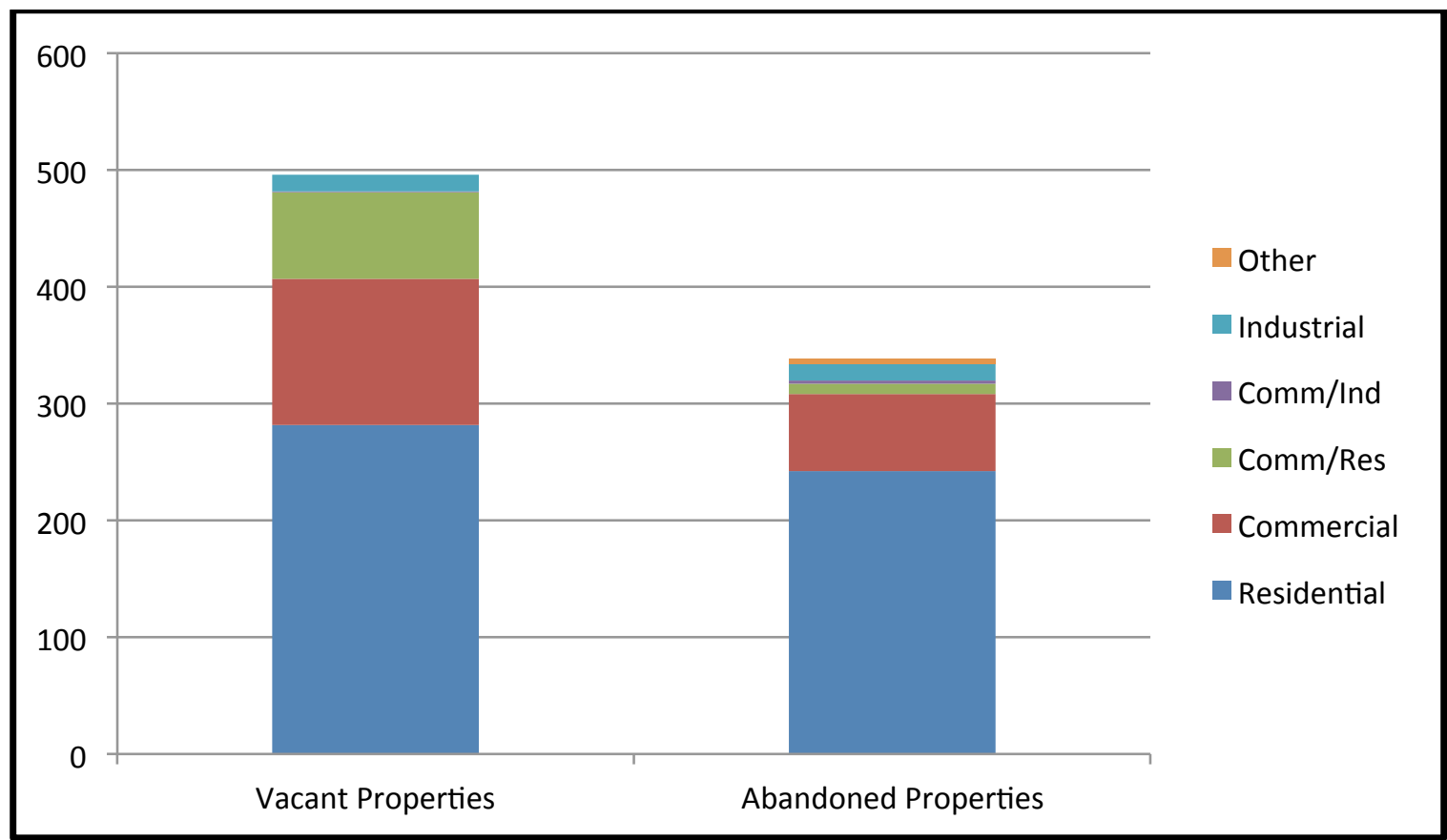

Of the 25 site visits conducted, 10 were residential, 9 were commercial and 6 were industrial. Although this is a small sample size, there was effort made to visit a range of sites across the city. Upon inspection, it became apparent that the sites ranged from wellmaintained vacant properties that were ready to be sold or rented, to dilapidated and vandalized properties that would take significant investment to inhabit or repurpose. This indicates that there is a wide range of typologies of vacant and abandoned properties.

The following sections identify and analyze vacant and abandoned properties by each use, namely: residential, commercial and industrial. 


\section{Residential Properties}

Vacant and abandoned residential properties are dispersed throughout the city as seen in Figure 5 below. There appears to be clustering of properties along the southern portion of the city (downtown) and out east to the former city of Scarborough. There is also clustering around the neighbourhoods of Willowdale and Lawrence Heights in the former city of North York. The map also shows that there are some areas of the city that are less affected by vacant and abandoned residential sites. These can be seen along the Don Valley Parkway and south of the 401 on either side of the 427. Possible explanations for these areas could be that there are less residential properties due to green space and industrial uses that dominated these locations.

\section{Figure 5: Vacant and Abandoned Residential Properties in Toronto}

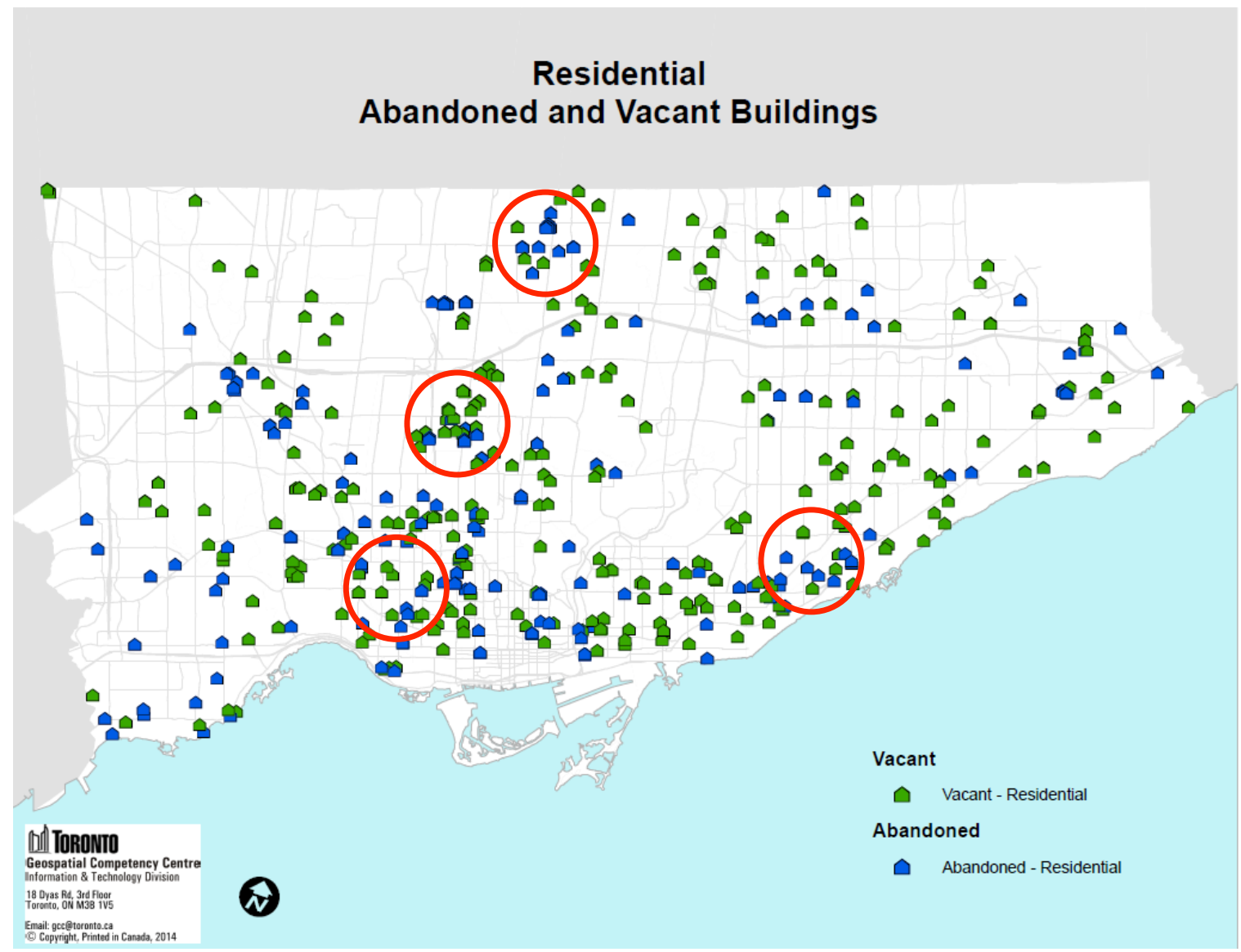

10 site visits were conducted of residential vacant and abandoned properties. Of these, 5 could be classified as dilapidated, where visual inspection of the property reveals broken 
windows, vandalism, overgrown yards and potential structural issues. Three of the 10 were well-maintained properties where yards were maintained, and from the street, it would be hard to identify that these properties as vacant. One property located on the waterfront in an affluent neighbourhood was found to be demolished upon the site visit; construction was underway for a new house on the site. Another site visit revealed a partially constructed house that had been framed and then apparently abandoned.

Of all the residential site visits, the most common element among the findings was the lack of impact residential vacancy has on the surrounding community. On one small residential street - where two houses are abandoned - the other houses appeared in good repair and well maintained. Another residential street had two severely abandoned homes adjacent to each other (with roofs collapsing), but right beside those properties appeared expensive downtown homes. One site was located in a neighbourhood that has adjacent properties worth millions of dollars. It appears that the impact of residential abandonment is contained within the parcel affected, and did not spread to the other properties. Further, residential abandonment did not seem to be harbingers of neighbourhood change. On the contrary, they seemed to be islands of disarray.

Figure 6: Summary of Residential site visits

\begin{tabular}{|l|l|l|l|l|}
\hline & Category & Location & Intersection & Comments \\
\hline 1. & Abandoned & $\begin{array}{l}\text { Inner } \\
\text { Suburb }\end{array}$ & $\begin{array}{l}\text { Birchmount } \\
\text { Rd./ Danforth } \\
\text { Rd. }\end{array}$ & $\begin{array}{l}\text { Half built house (wood framing } \\
\text { started). Fenced property, with } \\
\text { overgrown yard located on small } \\
\text { residential street. }\end{array}$ \\
\hline 2. & Abandoned & $\begin{array}{l}\text { Inner } \\
\text { Suburb }\end{array}$ & $\begin{array}{l}\text { Hwy 401/ } \\
\text { Weston Rd. }\end{array}$ & $\begin{array}{l}\text { Poorly maintained detached property } \\
\text { with broken windows, collapsing roof, } \\
\text { collapsed garage and overgrown yard. } \\
\text { Located on small residential street. }\end{array}$ \\
\hline 3. & Abandoned & $\begin{array}{l}\text { Inner } \\
\text { Suburb }\end{array}$ & $\begin{array}{l}\text { Hwy 401/ } \\
\text { Weston Rd. }\end{array}$ & $\begin{array}{l}\text { Dilapidated property with fencing and } \\
\text { a sign advertising new condominium } \\
\text { development. Located on major } \\
\text { arterial between high-rise private } \\
\text { rental buildings. }\end{array}$ \\
\hline 4. & Abandoned & $\begin{array}{l}\text { Inner } \\
\text { Suburb }\end{array}$ & $\begin{array}{l}\text { Hwy 401/ } \\
\text { Weston Rd. }\end{array}$ & $\begin{array}{l}\text { Overgrown and dilapidated detached } \\
\text { property with abandoned car on lawn. } \\
\text { Located on arterial road between high- } \\
\text { rise private rental properties. }\end{array}$ \\
\hline
\end{tabular}




\begin{tabular}{|l|l|l|l|l|}
\hline 5. & Abandoned & $\begin{array}{l}\text { Outer } \\
\text { Downtown }\end{array}$ & $\begin{array}{l}\text { Roncevalles } \\
\text { Ave. / Dupont } \\
\text { St. }\end{array}$ & $\begin{array}{l}\text { Well-maintained and boarded semi- } \\
\text { detached property on small residential } \\
\text { street. }\end{array}$ \\
\hline 6. & Abandoned & $\begin{array}{l}\text { Outer } \\
\text { Downtown }\end{array}$ & $\begin{array}{l}\text { Roncevalles } \\
\text { Ave. / Dupont } \\
\text { St. }\end{array}$ & $\begin{array}{l}\text { Well-maintained and boarded semi- } \\
\text { detached property on small residential } \\
\text { street. }\end{array}$ \\
\hline 7. & Abandoned & $\begin{array}{l}\text { Inner } \\
\text { Suburb }\end{array}$ & $\begin{array}{l}\text { Lakeshore } \\
\text { Blvd. W / } \\
\text { Brown's Line }\end{array}$ & $\begin{array}{l}\text { No longer abandoned. Building has } \\
\text { been demolished and is currently being } \\
\text { rebuilt. Property located on affluent } \\
\text { waterfront residential street. }\end{array}$ \\
\hline 8. & Abandoned & Downtown & $\begin{array}{l}\text { Bloor St. W/ } \\
\text { Bathurst St. }\end{array}$ & $\begin{array}{l}\text { Two dilapidated and attached } \\
\text { properties, boarded with unmaintained } \\
\text { yards and collapsing roofs. Located on } \\
\text { small downtown residential street. }\end{array}$ \\
\hline 9. & Abandoned & $\begin{array}{l}\text { Outer } \\
\text { Downtown }\end{array}$ & $\begin{array}{l}\text { Lawrence Ave } \\
\text { W. / } \\
\text { Avenue Rd. }\end{array}$ & $\begin{array}{l}\text { Large detached property with boarded } \\
\text { windows and unmaintained lawn. } \\
\text { Located on affluent residential street. }\end{array}$ \\
\hline 10. & Vacant & $\begin{array}{l}\text { Inner } \\
\text { Suburb }\end{array}$ & $\begin{array}{l}\text { Finch Ave./ } \\
\text { Weston Rd. }\end{array}$ & $\begin{array}{l}\text { Well-maintained property. Yard } \\
\text { maintained on small residential street. }\end{array}$ \\
\hline
\end{tabular}

Six examples of residential site visits can be found below. 


\section{Abandoned Residential (site visit \#1)}

Neighbourhood: Inner suburb

Intersection: Birchmount Rd. / Danforth Rd.

Description: Half built house (wood framing started). Fenced property, with overgrown

yard located on small residential street. This property is located in a quiet residential neighbourhood that is otherwise well-maintained. It appears that this property was abandoned mid-construction, which could have been a result of financing, building permits or planning approvals. Once left exposed over a period of time, framing will start to fall into disrepair and become dilapidated. If enough time passes, the building will have to be demolished before further construction can commence. In the mean time, the property remains fenced in order to secure it.

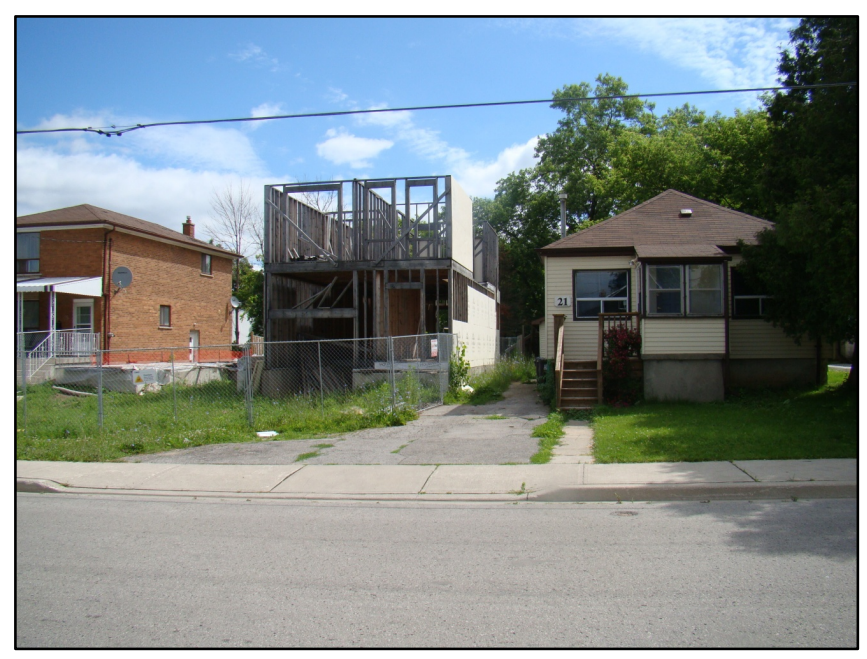

\section{Abandoned Residential (site visit \#3)}

Neighbourhood: Inner suburb

Intersection: Hwy 401 / Weston Rd.

Description: Detached house on dilapidated property, slated for demolition, with fencing and a sign advertising new condominium development. Located on major arterial between high-rise private rental buildings. This is an example of a property that was purchased by a developer and is likely awaiting planning approvals and financing before construction starts. A detached home like this is a beautiful place for people to live, but given the surrounding uses (high-rise) it makes sense to intensify the land use to align with surrounding uses. The fact that the property remains abandoned in the meantime, means that the community faces impacts due to the unsightly nature of the house and 
unkempt yard, but in the long run, increased density will bring more consumers to the neighbourhood, and taxes to the city, which will provide benefits.

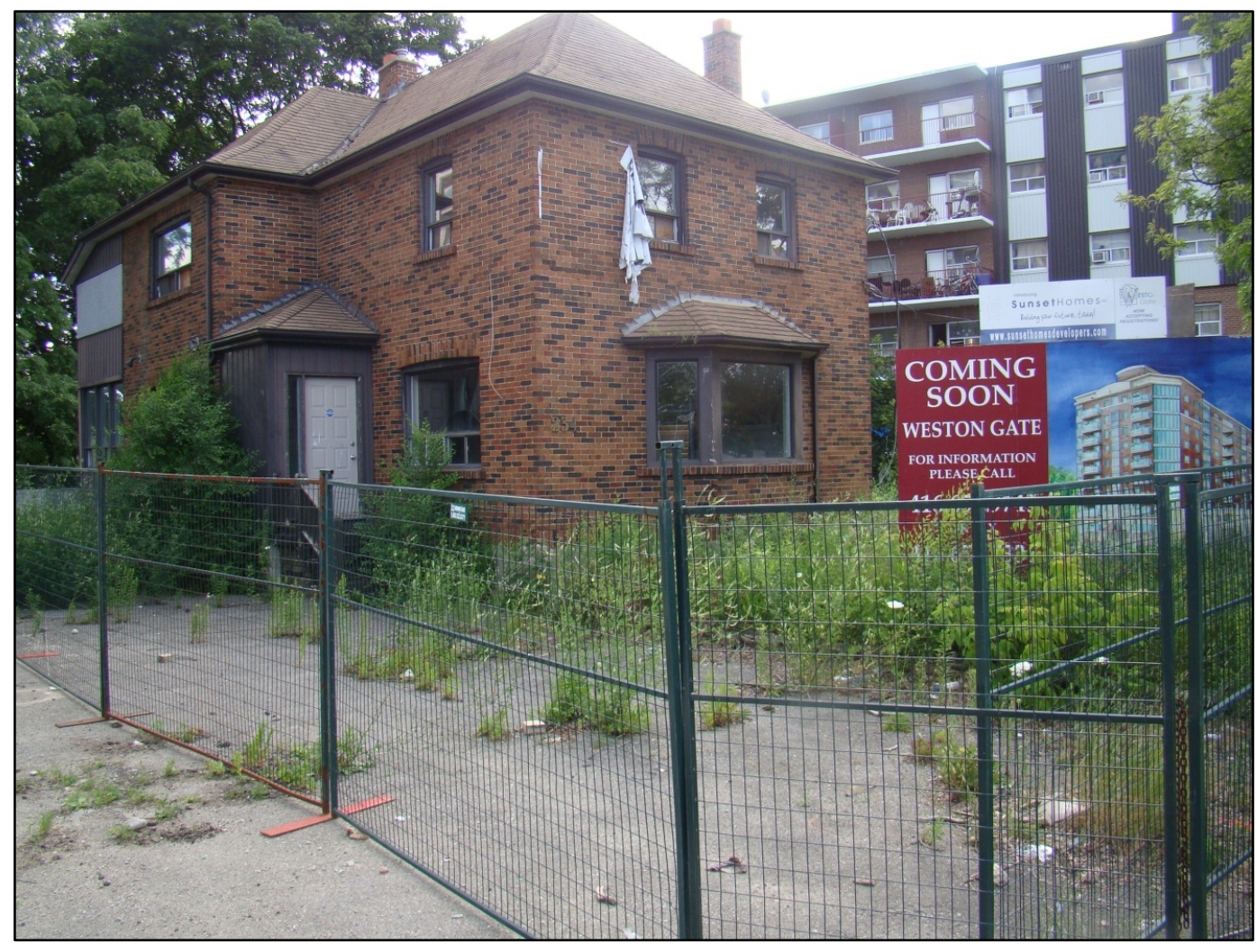




\section{Vacant Residential (site visit \#5)}

Neighbourhood: Outer Downtown

Intersection: Roncevalles Ave. / Dupont St.

Description: Well-maintained and boarded row house property on small residential

street. This property was difficult to identify as vacant from the curb. Situated amongst neighbouring row houses, the only identifier of vacancy is the boarded windows. There was another vacant house on this street a little further down as well, but despite these properties, the street remained vibrant and well-maintained. Neither of these vacant and boarded houses on the street were listed for sale, so it is hard to understand why the owners would leave the buildings.

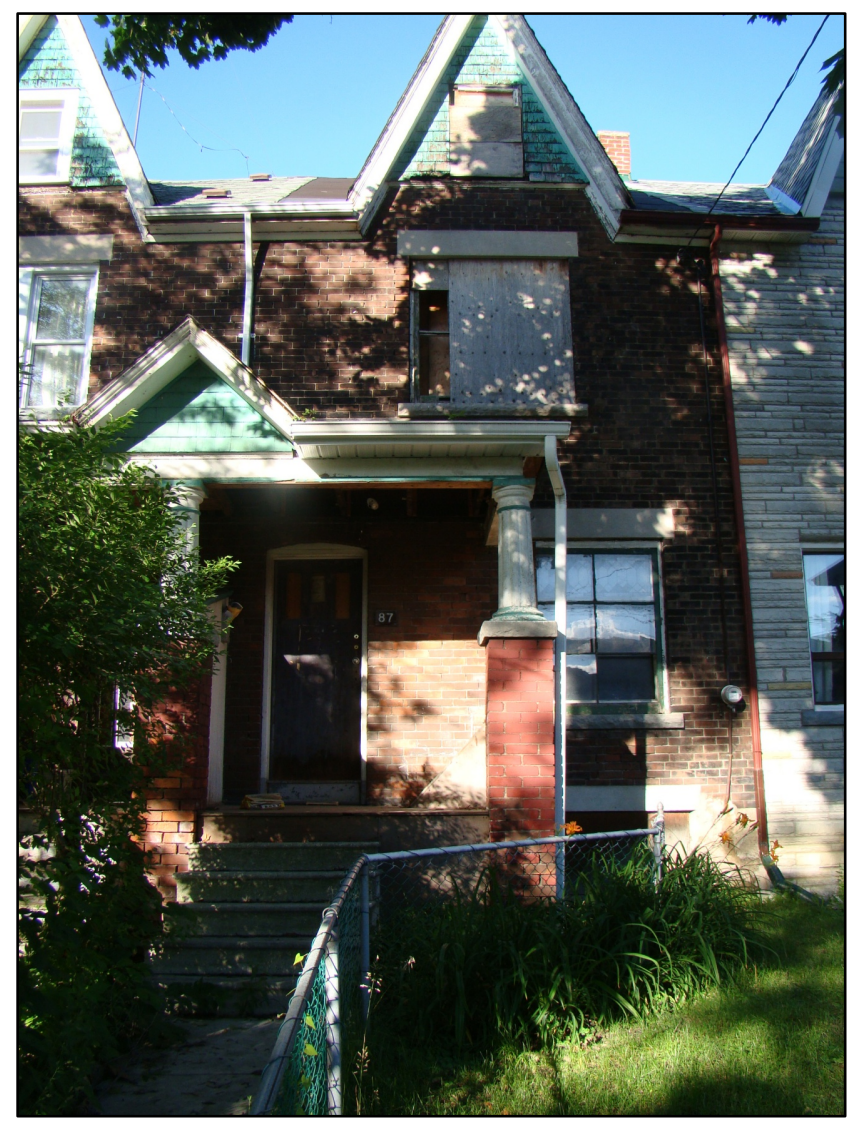

\section{Abandoned Residential (site visit \#8)}

Neighbourhood: Downtown

Intersection: Bloor St. W. / Bathurst St.

Description: Two dilapidated and attached properties, boarded with unmaintained yards and collapsing roofs. Located on small downtown residential street. Despite that fact that there are two properties adjacent to each other that have fallen into disrepair, the remainder of this street remains a high income and expensive downtown neighbourhood 
to live in. The buildings are most likely beyond repair at this point and will have to be demolished. It is likely that there is one owner for both properties and that when the properties are sold, there will be a planning application to annex both properties so that the rebuild will be double lot size, which is rare and valuable in a downtown context.

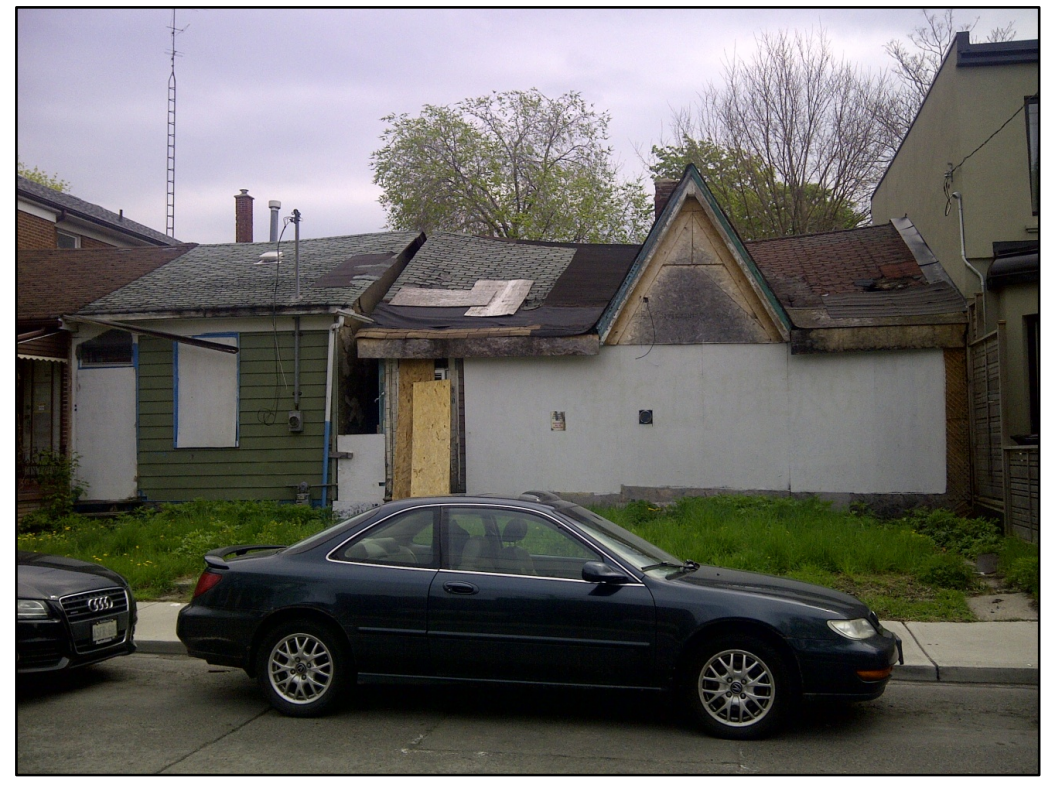

Source: City of Toronto, 2014

\section{Abandoned Residential (site visit \#9)}

Neighbourhood: Outer Downtown

Intersection: Lawrence Ave W. /Avenue Rd.

Description: Large detached property with boarded windows and unmaintained lawn.

Located on affluent residential street. The surrounding properties in this area are multimillion dollar homes. Despite the fact that the property is largely well-maintained it has been vacant apparently more than 10 years. The neighbours of this property are vocal

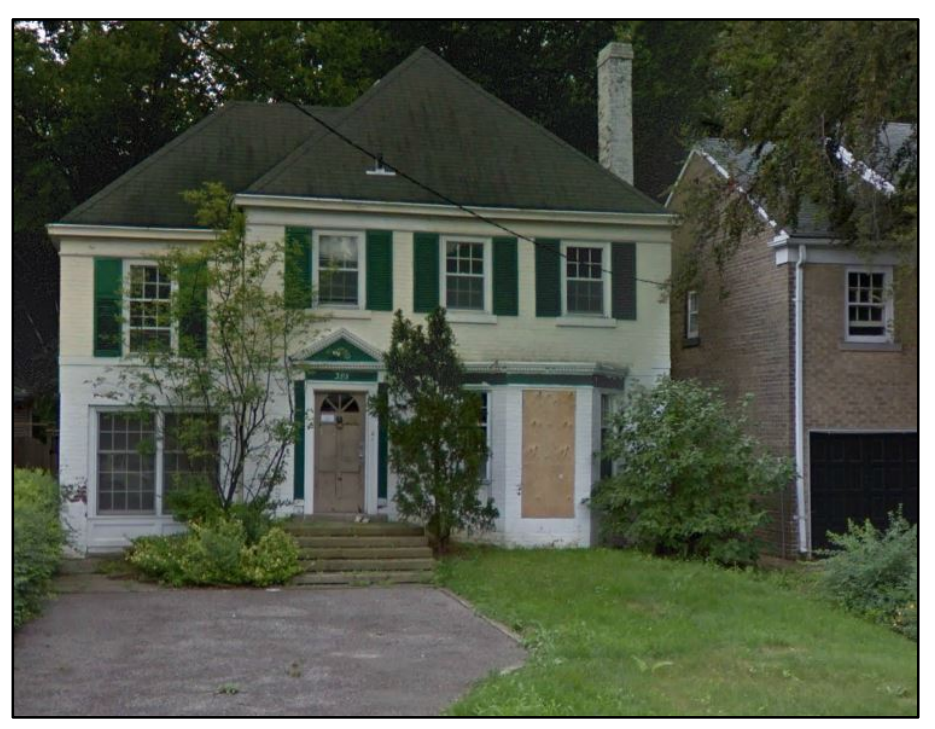

about the status of this property and have launched several complaints to the City (Toronto Star, Aug 2014). Although the property is technically in compliance with the bylaw, there is currently no authority to demand that a building be occupied, or sold. 


\section{Vacant Residential (site visit \#10)}

Neighbourhood: Inner suburb

Intersection: Finch Ave. /Weston Rd.

Description: Well-maintained vacant bungalow on small residential street. From the curb this house is difficult to identify as vacant. Although, upon closer inspection, you can see that that the main window has been secured with multiple wood doors. The lawn is mowed and the driveway and porch are clear of garbage. This bungalow is typical of post war construction of many of Toronto's inner suburbs and is surrounded by housing stock that is similar. The surrounding neighbourhood does not have any other signs of blight and the reasons for this vacancy remain unknown.

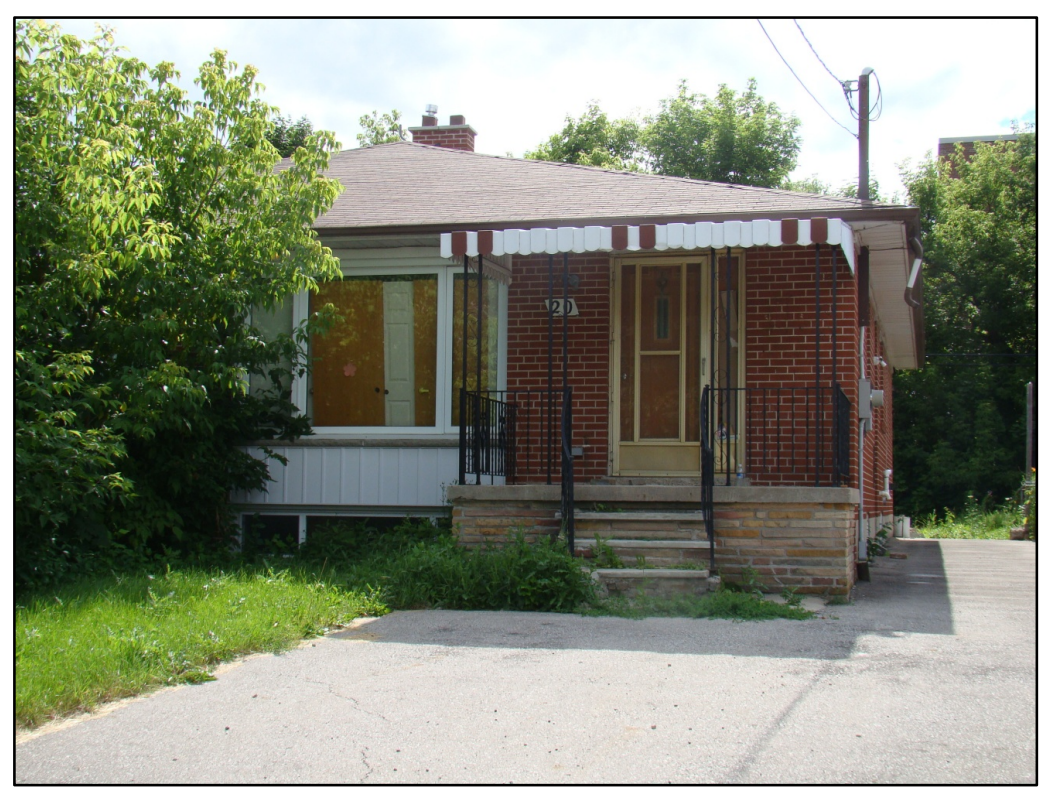




\section{Commercial Properties}

Vacant and abandoned commercial properties can be found along the 401 and congregated downtown. There are also several properties identified throughout midtown. Figure 6 below shows the location and distribution of vacant and abandoned commercial properties. The map identifies clusters of commercial vacancy along strips of commercial retail at Queen St. East, Gerrard St. East and Weston Rd.

There are more vacant commercial properties than abandoned, but both types of properties are found in the same areas. Upon site visit, several commercial sites were found to be leased to a new tenant or in good condition with a "for rent" sign, or building permits in the window. This indicated that commercial properties may become vacant, but then find new tenants, more quickly than other uses.

\section{Figure 7: Vacant and Abandoned Commercial Properties in Toronto}

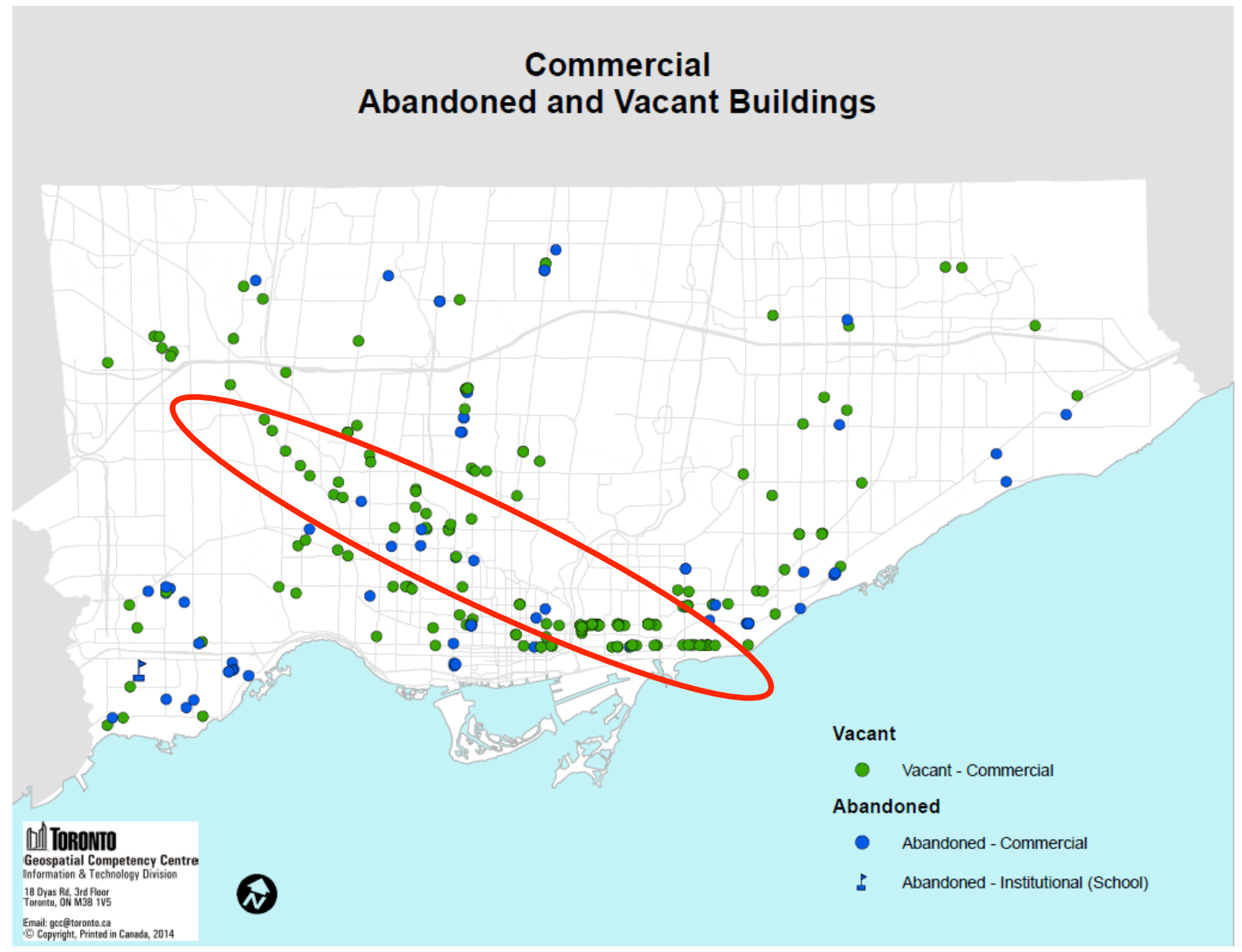


9 site visits were conducted on commercial vacant and abandoned properties. Of these, only 1 could be classified as dilapidated, where there was vandalism and broken windows. 6 of the 9 were well maintained or in the process of being renovated. 2 of the 9 were no longer vacant upon the site visit. In contrast to residential properties, the commercial site visits revealed a stock of viable commercial space that is mostly ready to be occupied. Even the one property that was dilapidated upon inspection had a 'for lease' sign on the door.

Figure 8: Summary of commercial site visits

\begin{tabular}{|c|c|c|c|c|}
\hline & Category & Location & Intersection & Comments \\
\hline 11. & Abandoned & $\begin{array}{l}\text { Inner } \\
\text { Suburb }\end{array}$ & $\begin{array}{l}\text { Danforth Rd. } \\
\text { / } \\
\text { Birchmount } \\
\text { Rd. }\end{array}$ & $\begin{array}{l}\text { Well-maintained property both inside } \\
\text { and out, with a "for rent" sign, } \\
\text { located just off main arterial. }\end{array}$ \\
\hline 12. & Abandoned & $\begin{array}{l}\text { Inner } \\
\text { Suburb }\end{array}$ & $\begin{array}{l}\text { Sheppard } \\
\text { Ave. W. / } \\
\text { Weston Rd. }\end{array}$ & $\begin{array}{l}\text { Currently being renovated. Located } \\
\text { on major arterial. }\end{array}$ \\
\hline 13. & Abandoned & $\begin{array}{l}\text { Inner } \\
\text { Suburb }\end{array}$ & $\begin{array}{l}\text { Gardiner } \\
\text { Expressway/ } \\
\text { Royal York } \\
\text { Blvd. }\end{array}$ & $\begin{array}{l}\text { Well-maintained property located } \\
\text { across from abandoned property and } \\
\text { vacant lot in industrial area near train } \\
\text { tracks. }\end{array}$ \\
\hline 14. & Abandoned & $\begin{array}{l}\text { Inner } \\
\text { Suburb }\end{array}$ & $\begin{array}{l}\text { Gardiner } \\
\text { Expressway/ } \\
\text { Royal York } \\
\text { Blyd. }\end{array}$ & $\begin{array}{l}\text { Well-maintained, strip commercial } \\
\text { building with parking out front } \\
\text { located adjacent to vacant lot and } \\
\text { across from abandoned commercial } \\
\text { property. Located in industrial area } \\
\text { near train tracks. }\end{array}$ \\
\hline 15. & Abandoned & Downtown & $\begin{array}{l}\text { Gerrard St. } \\
\text { E./ } \\
\text { Coxwell Ave. }\end{array}$ & $\begin{array}{l}\text { Vandalized and boarded large } \\
\text { commercial retail space located on } \\
\text { main arterial. }\end{array}$ \\
\hline 16. & Vacant & $\begin{array}{l}\text { Outer } \\
\text { Downtown }\end{array}$ & $\begin{array}{l}\text { Queen St. E. / } \\
\text { Main St. }\end{array}$ & $\begin{array}{l}\text { No longer vacant. New store on } \\
\text { premise. }\end{array}$ \\
\hline 17. & Vacant & $\begin{array}{l}\text { Outer } \\
\text { Downtown }\end{array}$ & $\begin{array}{l}\text { Queen St. E. / } \\
\text { Main St. }\end{array}$ & $\begin{array}{l}\text { No longer vacant. New store on } \\
\text { premise. }\end{array}$ \\
\hline 18. & Vacant & $\begin{array}{l}\text { Outer } \\
\text { Downtown }\end{array}$ & $\begin{array}{l}\text { Queen St. E. / } \\
\text { Main St. }\end{array}$ & $\begin{array}{l}\text { Storefront located on busy retail } \\
\text { strip. Building permits in windows } \\
\text { but no evidence of renovations } \\
\text { underway. }\end{array}$ \\
\hline 19. & Vacant & $\begin{array}{l}\text { Outer } \\
\text { Downtown }\end{array}$ & $\begin{array}{l}\text { Queen St. E. / } \\
\text { Main St. }\end{array}$ & $\begin{array}{l}\text { Well-maintained storefront for rent } \\
\text { located on busy retail strip with some } \\
\text { evidence of renovations, including } \\
\text { building permits. }\end{array}$ \\
\hline
\end{tabular}


Three examples of commercial vacant and abandoned properties can be found below.

\section{Abandoned Commercial (site visit \#13)}

Neighbourhood: Inner Suburb

Intersection: Gardiner Expressway / Royal York Blvd.

Description: Abandoned commercial property adjacent to vacant lot and across from

additional abandoned commercial property in industrial area near train tracks. With

ample parking space and ease of access to the highway, this property seems ripe for new tenants, except that the adjacent property and property across the road are an empty lot and a vacant building, respectively, lending to the sense that this area is in decline. This site visit stands out from the rest, since it truly seemed to be a cluster of vacant commercial buildings. This may be because these commercial properties are not appropriate for retail, since there are located far from transit or residential uses and are not easily rented to new businesses.

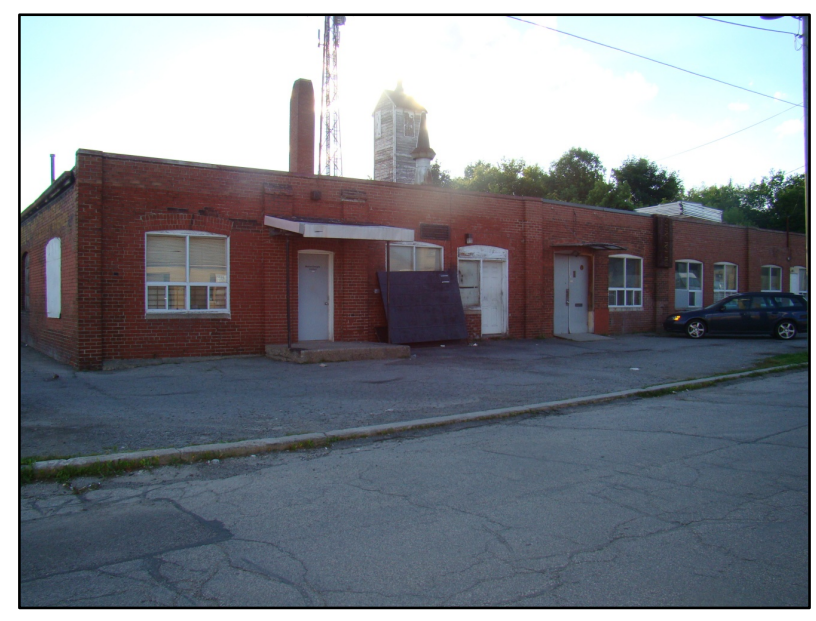

\section{Vacant Commercial (site visit \#15)}

Neighbourhood: Downtown

Intersection: Gerrard St. E. / Coxwell Ave.

Description: Vandalized and boarded large commercial retail space. Vacant and located on main arterial near other businesses, this space was formerly used as a dollar store, but has been unable to retain a new tenant. Despite this, the owners have been conducting renovations on the space to be able to attract a new business. The location of this building is near other commercial uses, although the neighbourhood overall suffers from significant commercial vacancy and is one of the last downtown neighbourhoods in 
Toronto to begin a gentrification process. Since the building has been under renovations, and because there are signs advertising the space for lease, one can assume that this property owner wants the building occupied but cannot find the right tenant.

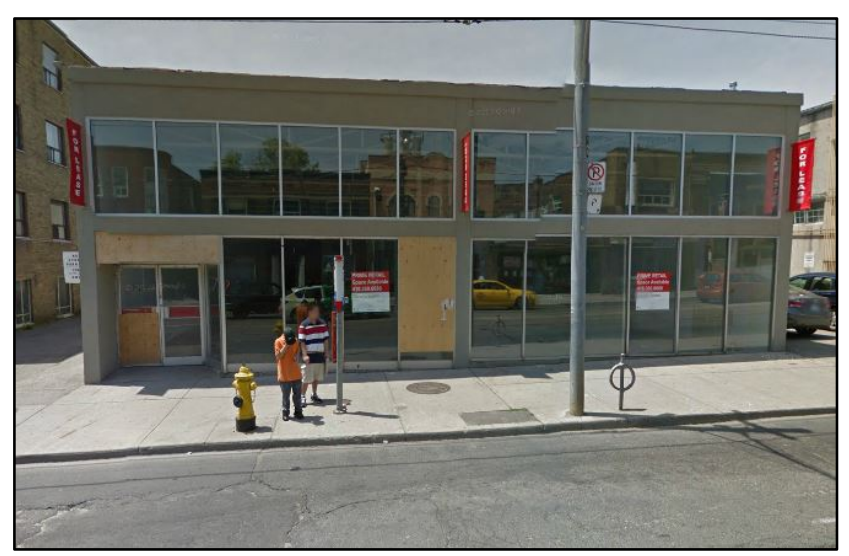

Source: Google Streetview, 2014

\section{Vacant Commercial (site visit \#18)}

Neighbourhood: Outer Downtown

Intersection: Queen St. E. / Main St.

Description: Vacant commercial property adjacent to another vacant commercial property. Storefront located on busy retail strip. Building permits in windows but no evidence of renovations underway. This strip of commercial retail space spans about 5 kms just outside of downtown. Surrounded by affluent residential neighbourhoods, this retail space remains desirable, but possibly expensive. Upon site visits to other noted addresses along the same strip, properties were found to be occupied. This could indicate that commercial retail space has high turnover compared to other types of vacancy.

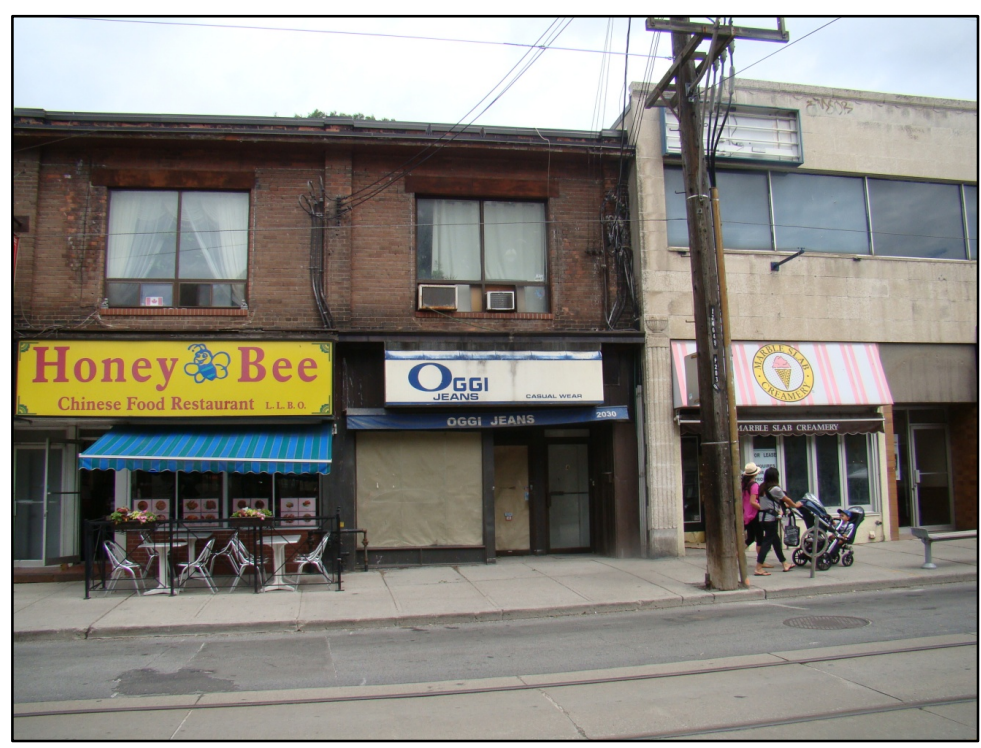




\section{Industrial Properties}

Vacant and abandoned industrial properties largely follow Toronto's railway corridor, which correlates with former manufacturing and industrial purposes. This makes sense, since the majority of industrial sites would be located where manufacturing occurred. Figure 7 below shows how industrial locations follow south from the 401 along the railway to downtown and then extends east along the waterfront and lakeshore railway corridor. There are no vacant or abandoned industrial spaces in midtown or centre of the city, where residential uses and green space prevails. Most strikingly, is that there are so few vacant and abandoned properties. Of the limited number of industrial properties affected, more are abandoned than vacant. This may indicate that once industrial properties become vacant, they are more likely to become abandoned, and stay abandoned. This could be because vacancy is due to larger shifts in economy, than tenancy issues. As well, lands used for industrial uses may be contaminated due to these uses and be less easily repurposed.

\section{Figure 9: Vacant and Abandoned Industrial Properties in Toronto}

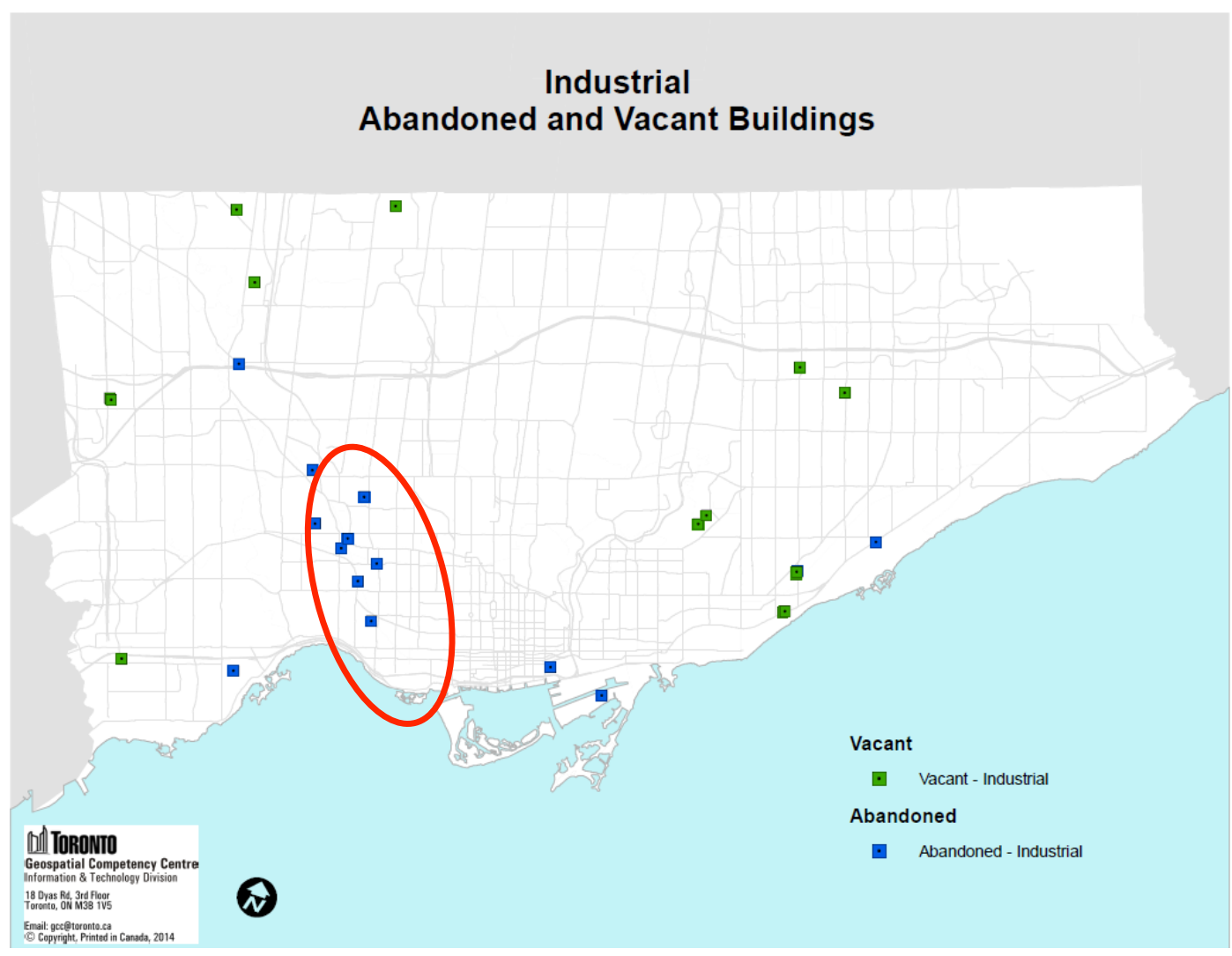


6 site visits were conducted on industrial vacant and abandoned properties. Of these, only 1 could be classified as dilapidated. 3 of the 6 were well-maintained light industrial properties. Although, of the well-maintained properties, 2 of the 3 were obviously abandoned and not actively looking for new tenants or owners. 2 of the 6 site visits revealed that the properties had been occupied for new purposes.

\section{Figure 10: Summary of industrial site visits}

\begin{tabular}{|c|c|c|c|}
\hline & Location & Intersection & Comments \\
\hline 20. & $\begin{array}{l}\text { Inner } \\
\text { Suburb }\end{array}$ & $\begin{array}{l}\text { Danforth Rd. / } \\
\text { Birchmount Rd. }\end{array}$ & $\begin{array}{l}\text { No longer abandoned. New light industrial } \\
\text { tenant. }\end{array}$ \\
\hline 21. & $\begin{array}{l}\text { Outer } \\
\text { Downtown }\end{array}$ & $\begin{array}{l}\text { Bloor St. W. / } \\
\text { Dundas St. W. }\end{array}$ & $\begin{array}{l}\text { Overgrown lawn, broken and boarded windows } \\
\text { of old manufacturing building. Located on main } \\
\text { arterial between commercial retail and artist } \\
\text { live/work lofts. }\end{array}$ \\
\hline 22. & $\begin{array}{l}\text { Inner } \\
\text { Suburb }\end{array}$ & $\begin{array}{l}\text { Sheppard Ave. } \\
\text { W. / Weston Rd. }\end{array}$ & $\begin{array}{l}\text { Well-maintained on outside of property but full } \\
\text { of items on the inside as observed through } \\
\text { windows. Located in light industrial area. }\end{array}$ \\
\hline 23. & $\begin{array}{l}\text { Inner } \\
\text { Suburb }\end{array}$ & $\begin{array}{l}\text { Danforth Rd. / } \\
\text { Birchmount Rd. }\end{array}$ & $\begin{array}{l}\text { Well-maintained property located on main } \\
\text { arterial with light industrial manufacturing uses } \\
\text { surrounding. }\end{array}$ \\
\hline 24. & $\begin{array}{l}\text { Inner } \\
\text { Suburb }\end{array}$ & $\begin{array}{l}\text { Danforth Rd. / } \\
\text { Birchmount Rd. }\end{array}$ & No longer vacant. New light industrial tenant \\
\hline 24 & $\begin{array}{l}\text { Inner } \\
\text { Suburb }\end{array}$ & $\begin{array}{l}\text { Hwy } 400 \text { / } \\
\text { Steeles Ave. W. }\end{array}$ & $\begin{array}{l}\text { Well-maintained light manufacturing property, } \\
\text { located in industrial park. }\end{array}$ \\
\hline
\end{tabular}

Four examples of vacant and abandoned industrial properties can be found below.

\section{Abandoned Industrial (site visit \#21)}

Neighbourhood: Outer Downtown

Intersection: Bloor St. W. / Dundas St.

Description: Abandoned manufacturing warehouse on main arterial, with overgrown lawn, broken and boarded windows. Located between commercial retail and similar building that has been repurposed as artist live/work lofts. Many of these types of manufacturing buildings have been converted into expensive hard loft condominium development in Toronto. This neighbourhood boasts several new condominium developments and is located close to transit and gentrifying residential neighbourhoods. It is possible that buildings like this are purchased by developers who apply for rezoning to allow residential uses. 


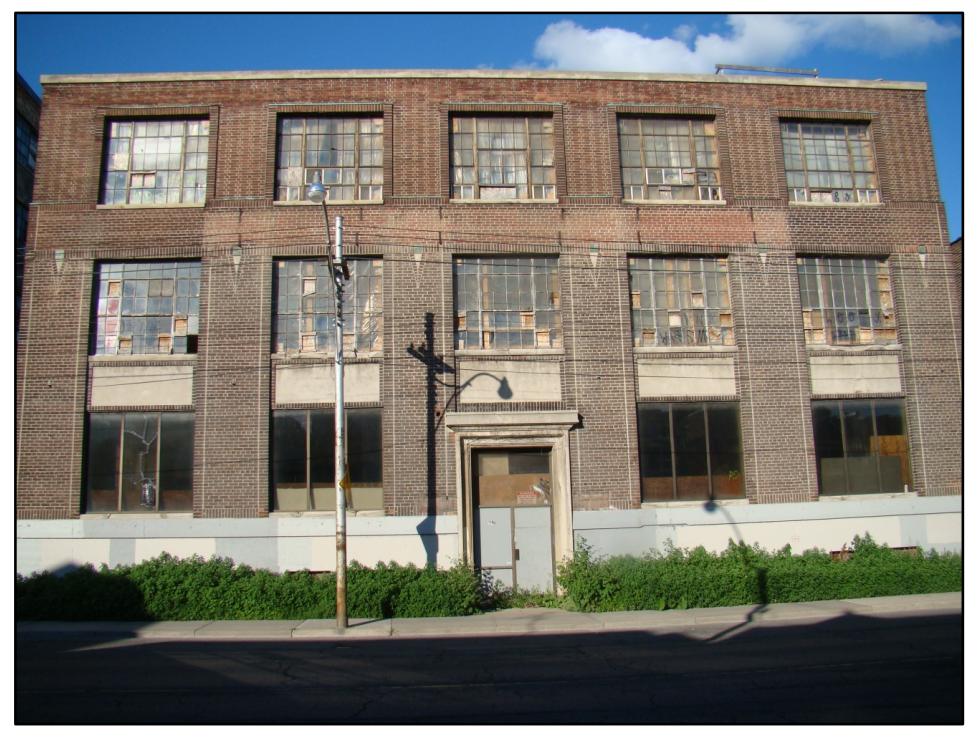

Vacant Industrial (site visit \#22)

Neighbourhood: Inner Suburb

Intersection: Sheppard Ave. W. / Weston Rd.

Description: Well-maintained vacant building in light industrial area. Upon closer inspection, interior of building was packed full of items and boxes which could present potential fire hazard. Surrounding uses in this area included light manufacturing, garages and body shops. There was no evidence of other vacant properties in this area and the interior state of this building indicates that the owner is not in the process of actively looking for a new tenant. Tax rebate programs from the city, may subsidize this use of the land, and permit properties like this one to be underutilized.

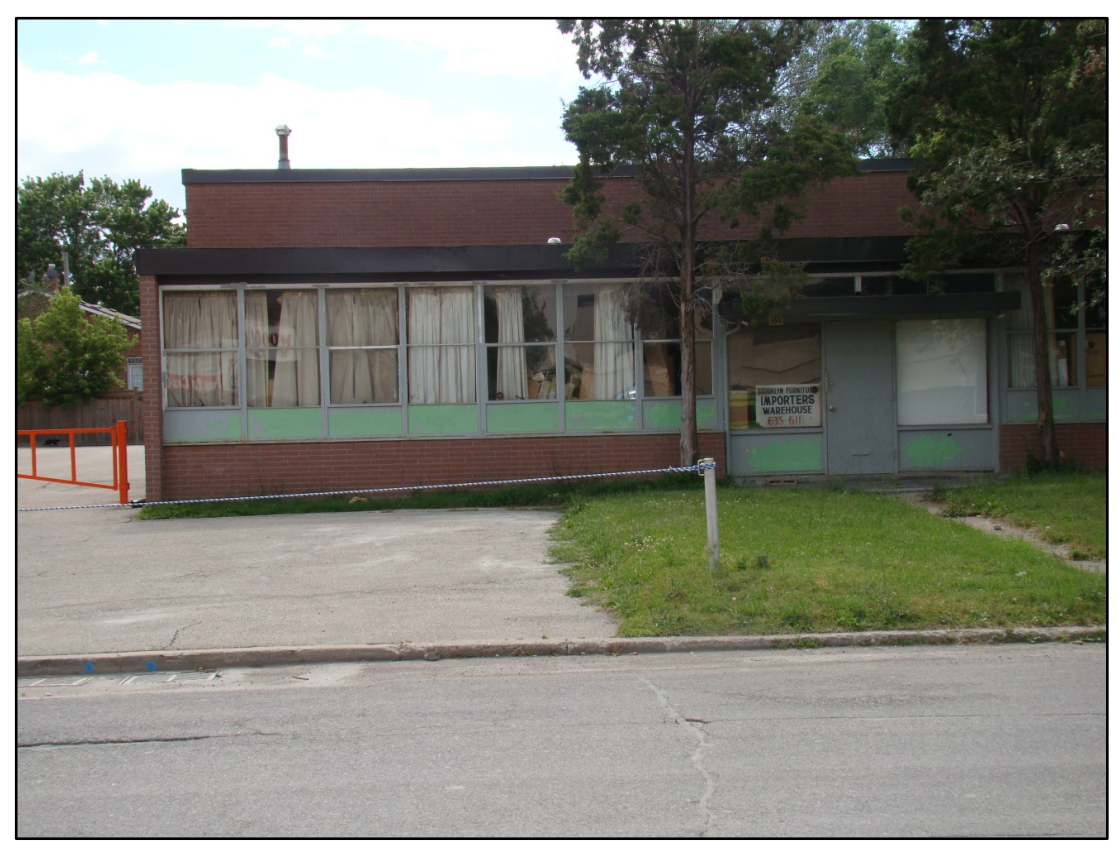




\section{Vacant Industrial (site visit \#23)}

Neighbourhood: Inner Suburb

Intersection: Danforth Rd. / Birchmount Rd.

Description: Well-maintained property located on main arterial with light industrial manufacturing uses surrounding. This building appeared to be permanently vacant due to the fact that entrances seemed to be permanently sealed. Both the front and sides of the building remained landscaped and parking lot was clean and maintained. This arterial road has several other light industrial businesses that seemed lively upon site visit. Since the building is well-maintained, and apparently not falling into disrepair, the owner of this site might be awaiting better resale prices (mothballing).

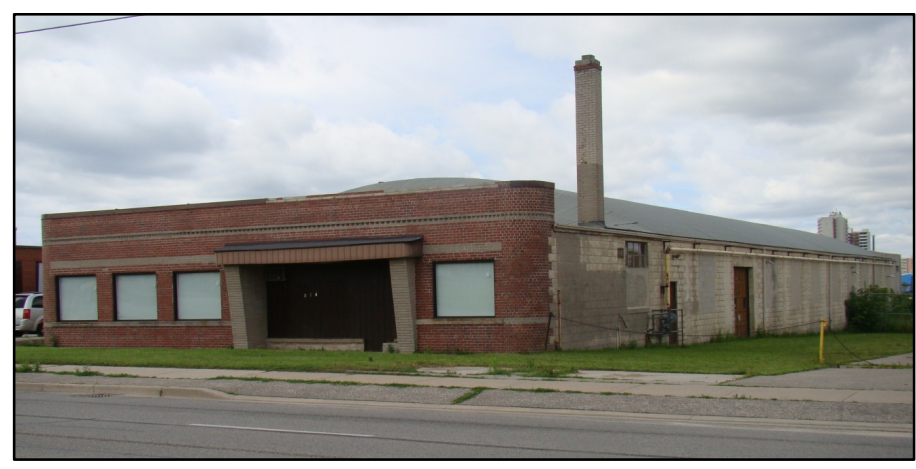

\section{Vacant Industrial (site visit \#24)}

Neighbourhood: Inner Suburb

Intersection: Hwy 400 / Steeles Ave. W.

Description: Well-maintained light manufacturing property, located in industrial park.

There was a sign in the window advertising that the space was available for lease. The property was well landscaped and the parking lot was clean and maintained. Located in an industrial park, close to a main highway, the surrounding uses in this area were light manufacturing and goods production.

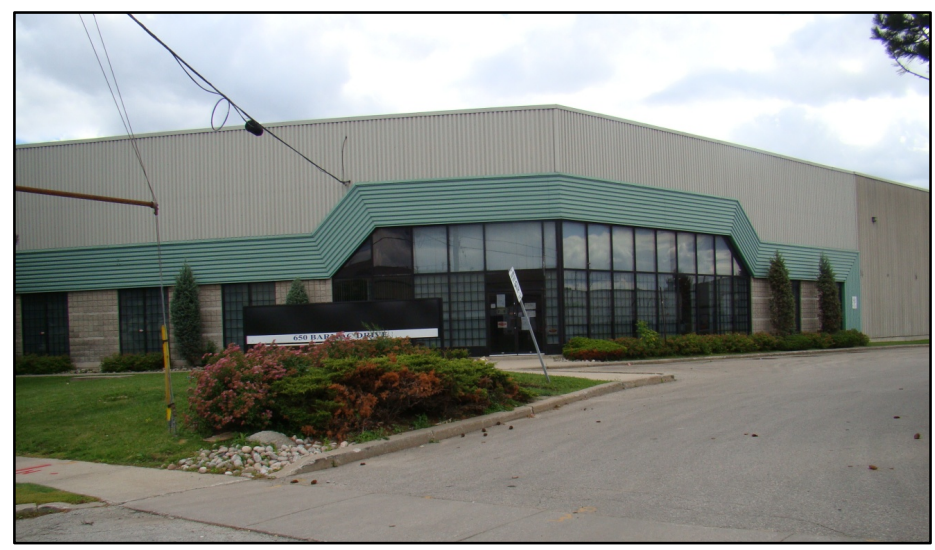




\section{Results and Discussion}

The issue of vacancy and abandonment in Toronto is distinct from more prolific examples as seen in the US. Less than $0.1 \%$ of properties in Toronto are classified as vacant or abandoned. This is a minimal percentage, yet when analysis of the distribution of the sites was conducted, it became clear that it is a small, but dispersed issue. There was little significant clustering, as could be imagined in other cities that may have been impacted by loss to manufacturing, or neighbourhood decline, that would result in distinct clusters of abandonment. In contrast, Toronto's vacant and abandoned properties are insidious in nature.

525 out of the 835 vacant and abandoned properties are residential. This represents the largest percentage of the properties (63\%). Much of the literature speaks to abandonment of housing stock due to shrinking populations and changing economies (Morckel, 2014; Han, 2014), but there is minimal research on residential vacancy compared to other types of abandonment (commercial or industrial). It became apparent that in Toronto, residential vacancy and abandonment are spread throughout the city. Indeed, all wards were affected by these types of properties. There seemed to be some clusters of residential properties located in specific neighbourhoods, but more astonishing, was the disaggregate nature of the distribution. These findings are different from the bulk of the literature, where many studies suggest that abandonment is a contagion, affecting surrounding properties (Han, 2014; Morckel, 2014; Accordino \& Johnson, 2008).

The site visits revealed several types of residential vacancy and abandonment. The sites ranged from extreme abandonment, to partial construction, to vacancy that would not be apparent from the street. It can be surmised that reasons for residential vacancy can be more affected by personal circumstance, than the reasons commercial and industrial properties become vacant. Examples of why residential properties become vacant include: finance issues, estate issues, lack of rental tenancy and aging. Residential vacancy can also occur because developers are awaiting planning approvals, or site acquisition of adjacent properties. The combination of personal and business interests in residential properties may be the reason why there is more residential vacancy than 
commercial and industrial vacancy. Finally, housing stock can fall into disrepair even when people do live at the property as can be seen with poverty and aging-in-place examples, so residential vacancy does not necessarily mean that the housing stock is in disrepair, and this was confirmed through the site visits that showcased many properties that were well-maintained and not necessarily noticeably 'vacant' from the street.

Commercial properties in Toronto are most often designated vacant (72\%) compared to abandoned (28\%). Commercial properties were most likely to have already been occupied upon site visit, and this may indicate that commercial properties are more fluid in occupancy than residential and industrial properties. Commercial-retail space is subject to market shifts, start-up business ventures and fickle consumer choice which can lead to temporary vacancy. In Toronto, commercial properties that are vacant are eligible for property tax rebates. This has recently become a point of discussion for local councillors as the City of Toronto prepares to raise this with the province (who would have the power to change the rebate program). The property rebate program was established to help bridge expenses due to lags between tenancies and to support small commercial building owners (City of Toronto, 2014).

The smallest proportion of vacant and abandoned buildings was industrial. Only 28 properties were identified as vacant and abandoned industrial in Toronto and it may be that these sites are no longer suitable for modern manufacturing. These properties followed the railway corridor in Toronto, with many sites falling very close to the rail line. This is consistent with the understanding that industrial lands in Toronto were located close to railways with easy access to shipping, along with properties that could be utilized for hazardous or noxious uses associated with industrial lands. Toronto's waterfront was also a place with significant industrial uses in the past, although there was no evidence of industrial vacant and abandoned clusters near the waterfront. This may be in part explainable by the immense condominium redevelopment of Toronto's waterfront that has seen much of these lands rezoned for high-density residential development. 
Upon analysis of the properties affected by vacancy and abandonment, it became evident that the categories of 'vacant' and 'abandoned' were less unifying than the categories of residential, commercial and industrial land uses. This may indicate that vacancy and abandonment causes and issues affect residential, commercial and industrial lands differently. The tendency to use the terms 'vacant' and 'abandoned' as interchangeable in the literature (Han, 2014) also indicates that these terms may not have a discernible difference.

\section{Revisiting the definitions of Vacancy and Abandonment}

There is discrepancy in the literature as it relates to the definitions of vacant, abandoned, derelict and brownfield properties (Wachsmuth, 2008, Morckel, 2014; Han, 2014). At the onset of the research the definition of 'vacant' and 'abandoned' was adopted and consistently used during methodology and analysis phases. This was consistent with the definition originally provided by Toronto Fire Services with the list of identified properties. Upon the onset of the research, it was assumed that the most significant differences would be found between 'vacant' properties and 'abandoned' properties. During the course of the research, one of the most significant findings was that this was not true, as the biggest differences were found between the uses of the land. This led to a change in the reporting of the results, in that the analysis was conducted by residential, commercial and industrial uses, where originally the plan was to compare vacant to abandoned properties. To this end, vacancy and abandonment are arguably not appropriately described as two distinct categories. 


\section{Figure 11: Vacancy and abandonment as distinct categories}
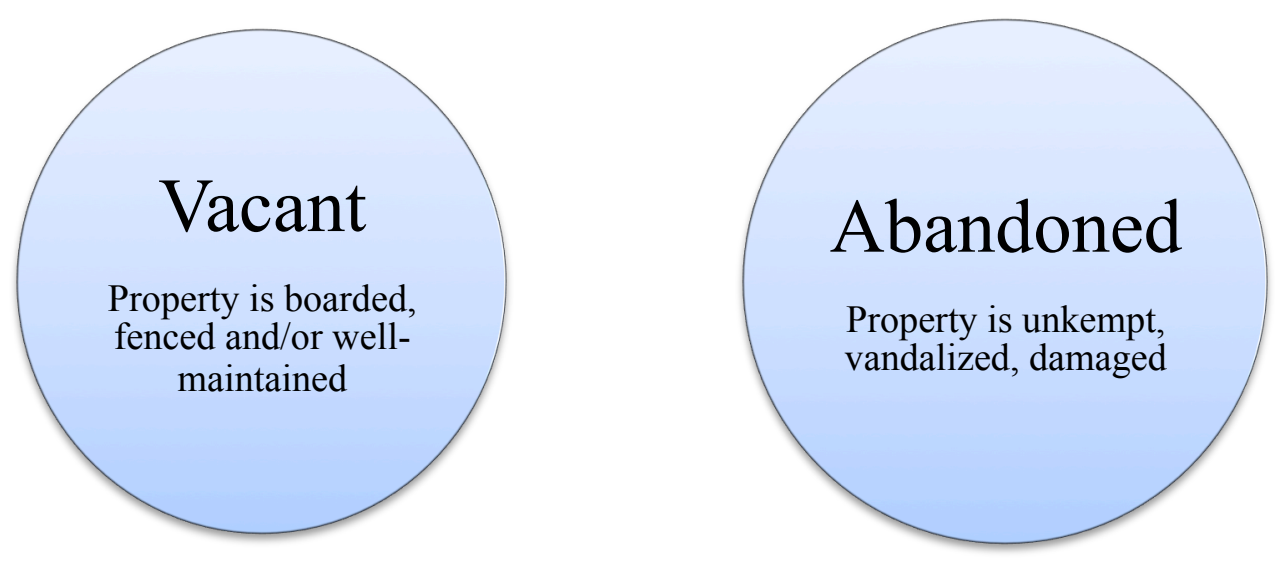

After analysis and consideration, it appears that vacancy and abandonment are part of the same contingent, in that vacancy issues are more of a 'sliding scale'. If vacancy is thought of as a sliding scale, then the status of 'vacant' would be found on one end of the spectrum with 'abandonment' on the other end. In between the two extremes of the spectrum, would be all the stages between vacancy (i.e., when a building first becomes vacant) to abandonment (i.e., when a building falls into irreversible structural disrepair). The transition time between the two ends of the spectrum is partially equated to the time that elapses since the last occupancy of the site.

Figure 9 shows pictorially the process of vacancy in the context of Toronto. Initially a property may become vacant because of several reasons. This is consistent with existing research that shows abandonment is a process, not a state (Wachsmuth, 2008; Katyoka \& Wyatt, 2008). Some examples of why vacancy and abandonment occurs may include when a commercial lease ends, and the tenant vacates the space, or when a developer purchases a property with the intent to redevelop it, or when the owner passes away and ownership is transferred into the estate. Vacancy can also occur when owners believe that 
over time a property may become more valuable, so owners hold property and wait for property values to rise until they choose to sell, a phenomenon called 'mothballing'.

After the initial vacancy, the property is left for a period of time. It may be that the space is easily rented again, or sold to another owner quickly. In other cases, time elapses. This may be due to estate issues, inability to rent or sell the property due to external market pressures or in the case of development, the time it takes to amass several adjacent properties for redevelopment. During this time, properties can fall into disrepair, attract vagrants and impact communities. After enough time elapses, the property will eventually become 'abandoned'. A more appropriate word for this status may be 'derelict' because the term 'abandoned' implies that the owners have permanently left the property, which is not necessarily the case.

\section{Figure 12: Vacancy as a process}

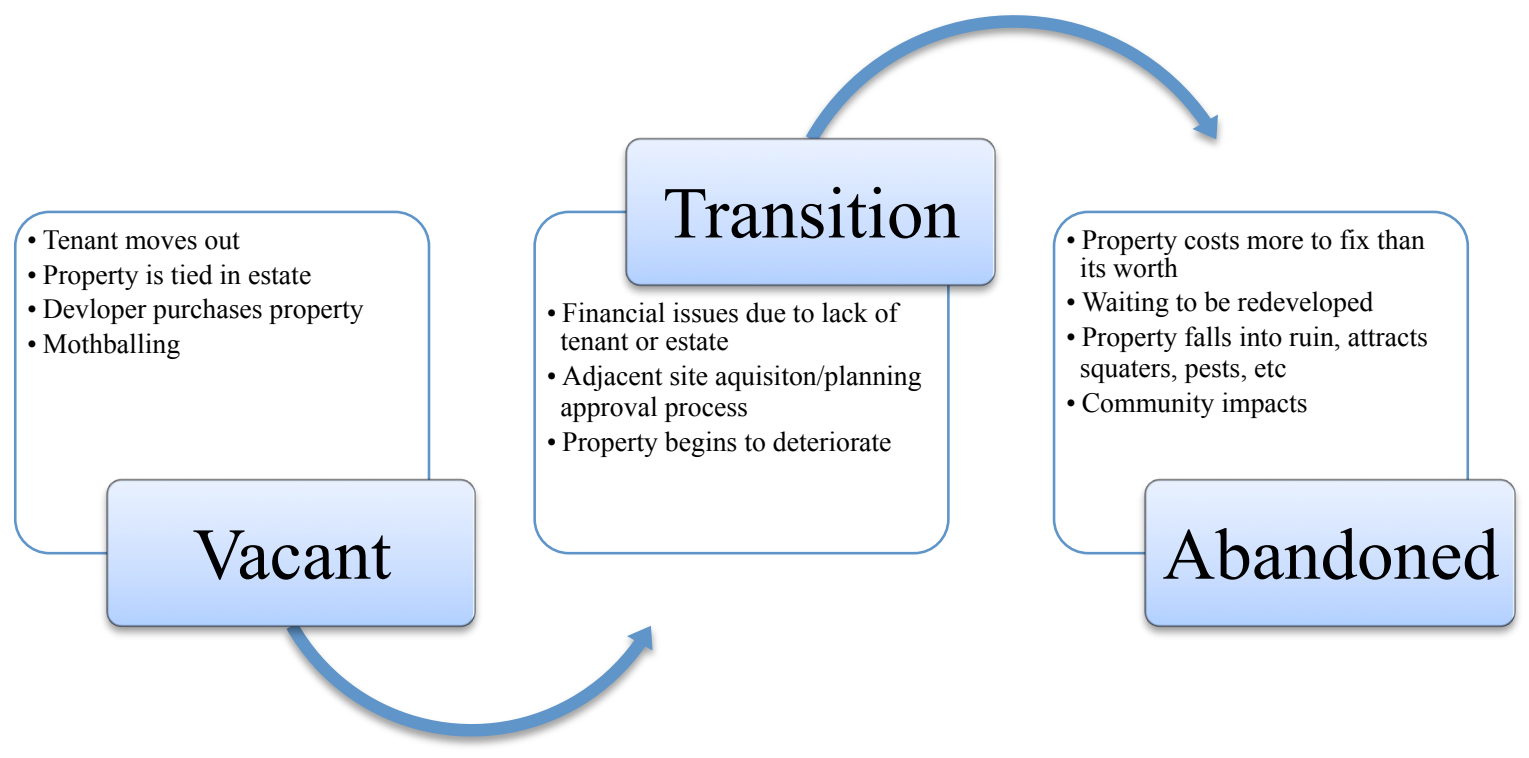

At this point, Figure 9 (above) remains a hypothesis of the transition of vacancy to abandonment/derelict status within the context of Toronto. The process of the building sliding from vacant to abandoned could be explained through a series of phases, that could be identified through physical characteristics, or by the amount of time elapsed, for example: initial vacancy (1-3 months), maintained vacancy (4-24 month), decline (24-36 months), abandonment (more than 36 months vacant). 
It would be beneficial to test this process through another study that could confirm its applicability. Further, it would be beneficial to examine the transferability of this concept to other cities that are experiencing growth, redevelopment and low vacancy rates similar to Toronto.

\section{Reasons for Vacancy}

The reasons that properties become abandoned are complex and multi-faceted. This makes it difficult to understand the problem and to recommend interventions to prevent it (Accordino \& Johnson, 2008).

Familial issues can impact issues of vacancy and abandonment on a micro-scale. Families are affected by estate issues and parents who age into elderly care leaving their properties vacant. These reasons impact residential vacancy issues and are hard to address on a large scale because of their individual nature. In the US and other countries, sub-prime mortgages impacted individual families ability to pay for their mortgages and left whole communities with strips of vacant and abandoned properties. This is not the case in Toronto, where banking regulations and strong economy largely prevented these issues.

External market pressures that affect global economies can impact local vacancy of commercial and industrial properties. As North America moved away from local manufacturing, in favour of inexpensive offshore labour, commercial and industrial properties were left to find new purposes and tenants. In Toronto, land that was originally used for industrial and manufacturing have been redeveloped into expensive high-rise condominium development and hard loft conversions that have seen manufacturing buildings converted to housing or live/work units.

Finally, it can be hypothesized in Toronto that a significant number of sites remain vacant or abandoned due to pressures resulting from the unprecedented amount of development and growth occurring in the city. Redeveloping land in Toronto is a long process that includes several barriers, including awaiting planning approvals and public consultation. 
The reasons for vacancy and abandonment ask more questions than can be answered by this research, but it important to contextualize the baseline information presented in this report. These questions form a strong basis for future research in vacant and abandoned buildings in Toronto.

\section{Cost of Vacancy}

The literature identifies significant costs to vacant and abandoned properties (Han, 2014).

Individual decisions to keep properties vacant, or allowing properties to fall into disrepair, means that communities bear the cost of the individual choice. Vacant and abandoned buildings attract pests, vandalism and are at increased risk for fire and squatters. It has also been linked to devalued property value for surrounding properties (Han, 2014).That is why cities regulate vacant and abandoned properties. Owners are expected to maintain their sites to certain level of standards, but city staff will maintain yards, fence properties and board windows in an effort to increase safety and protect communities from the negative impacts associated with these types of properties, if owners fail to comply.

Other city services can also be impacted by vacancy, these include emergency response services such as Fire and Police. When properties have been left to deteriorate on the inside, it may not be evident from the outside of the building, which leaves Police and Fire fighters at risk for injury when responding to calls about these properties. 


\section{Conclusion}

Despite the fact that the city of Toronto is in the midst of unprecedented development fuelled by low-interest mortgage rates, foreign investment and staggering commute times, a small percentage of properties remain vacant or abandoned. This paper identified the types of properties that are vacant and abandoned in Toronto and analyzed them for use and distribution. It became apparent that residential, commercial and industrial vacancy is distributed differently throughout the city. Further, it seemed that the reasons for vacancy are dependent on the use of the property. In that, a residential property may become vacant due to estate or financial issues, mothballing or because a developer is awaiting planning approvals to redevelop the land, where commercial vacancy may have more transient vacancy that is less likely to transition to abandonment since new tenants or businesses can acquire the space easily, compared to former industrial uses, that seem to be most affected by abandonment, and not vacancy, which could be because of more permanent changes such as deindustrialization.

There is significant research in the literature on the impacts and tools to address vacancy and abandonment in an American deindustrialized city with shrinking populations. The bulk of this research looks at the devastating effects of mass abandonment due to deindustrialization and subprime mortgages, but there is very little research on the impacts of vacancy in cities that face extreme development pressures.

The research conducted for this paper indicates that issues of vacancy and abandonment in Toronto may be different from American cities that face extreme levels of abandonment in the wake of deindustrialization. As well, Toronto's regulatory context has strong policies that direct growth to urban centres, promote reuse and mandate intensification. The findings from this paper may be able to be applied to other cities that face similar regulatory contexts, development pressures, strong economies and low vacancy rates as found in Toronto.

Finally, at the onset of this research, the data was categorized by use (residential, commercial or industrial) and then by state (vacant or abandoned). Upon completion of 
the site visits and through further research, it became apparent that the terms 'vacant' and 'abandoned' are not binary states, but are two ends of a process. Where vacant buildings would seem to give minimal impacts to community and safety, abandoned buildings are the largest risk to these concerns. Where some properties become vacant for a period of time, but then find new uses or tenants, others slide into abandonment. The reasons why properties become abandoned, the time it takes for properties to become abandoned and the tools to prevent this transition from occurring would seem to be distinct. So if the issues that cause short periods of vacancy are different then the issues that cause buildings to fall into abandonment, it is important that policy and research reflect these differences. 


\section{Appendix A}

Visual Inspection Chart

take photos of the building and note relevant information

Site Address:

Site Category (circle one)

Vacant Abandoned

Site Use (circle one)

Residential Commercial Industrial

Property Features:

Describe the property (quality of building \& landscape)

Describe its locational context

Level of vacancy or abandonment?

Neighborhood Convenience:

Proximity to downtown

Are shopping centers and restaurants nearby?

Is there a park or playground nearby?

Is there public transportation available? 


\section{Neighborhood Quality}

What is the shape of nearby homes/buildings?

What is the neighborhood like in terms of people (age structure), buildings, general quality?

Is there heavy traffic or noise?

What is your sense of crime or vandalism, litter or pollution?

Are there good public services (i.e., police, fire, etc.)?

Is there adequate parking?

Are there factories or heavy industry near by?

Are there any other sources of potential contamination (old gas station, etc.)

What is your overall rating of the neighborhood?

Other: 


\section{References}

Accordino, J. \& Johnson, G. (2000). Addressing the Vacant and Abandoned Property Problem. Journal of Ubran Affairs, Volume 22, Number 3, pages 301 - 315. http://journals1.scholarsportal.info.ezproxy.lib.ryerson.ca/pdf/07352166/v22i0003 /301_atvaapp.xml

Branas, C. C., Rubin, D., \& Guo, W. (2012). Vacant properties and violence in neighborhoods. ISRN Public Health, doi:http://dx.doi.org/10.5402/2012/246142

City of Toronto (2014) How Does the City Grow. July 2014. http://www1.toronto.ca/wps/portal/contentonly?vgnextoid $=3$ cee 3851 be $402410 \mathrm{Vg}$ $\underline{\text { nVCM10000071d60f89RCRD\&vgnextchannel=1e68f40f9aae0410VgnVCM1000 }}$ $\underline{0071 d 60 f 89 R C R D}$

City of Toronto (2010) Official Plan. http://www1.toronto.ca/wps/portal/contentonly?vgnextoid $=03 \mathrm{eda} 07443 \mathrm{f} 36410 \mathrm{Vg}$ $\underline{\text { nVCM10000071d60f89RCRD }}$

City of Toronto (2014) Redesigning the Vacant Commercial and Industrial Tax Relief Program to Stimulate Economic Growth (Collaborating For Competitiveness, Implementation Action 8).

City of Toronto. (2014) Stimulating Development in Underutilized Areas. July 7, 2014 http://www.toronto.ca/legdocs/mmis/2014/pg/bgrd/backgroundfile-71961.pdf

Emporis (2014). Retrieved from: http://www.emporis.com on June 15, 2014

Environmental Protection Agency (2014) retrieved July 2014, http://www.epa.gov/brownfields/overview/glossary.htm 
Davis, T. A. (2012) A comparative analysis of state and local government vacant property registration statutes. The Urban Lawyer, 44(2), 399 -427

Hackworth, J. (2013) The limits to market-based strategies for addressing land abandonment in shrinking American cities. Progress in Planning. Volume 90, May 2014, Pages 1-37 http://www.sciencedirect.com.ezproxy.lib.ryerson.ca/science/article/pii/S0305900 $\underline{614000191 ? \mathrm{np}=\mathrm{y}}$

Han, H. (2014) The Impact of Abandoned Properties on Nearby Property Values. Housing Policy Debate, 2014 Vol. 24, No. 2, 311-334. Taylor \& Francis. http://dx.doi.org/10.1080/10511482.2013.832350

Hirokawa, K. \& Gonzalez, I. (2010) Regulating vacant property. The Urban Lawyer, 42(3), 627-637

Home, R. (1983) Inner city vacant land : UK policies Butterworth and Co (Publishers) Ltd. http://journals2.scholarsportal.info.ezproxy.lib.ryerson.ca/pdf/02642751/v01i0001 159 icvl.xml

Katyoka, M. \& Wyatt, P. (2008). Planning, Practice \& Research. Vol 23, No. 1, 125-145

Morckel, V. (2014) Predicting abandoned Housing: Does the operation definition of abandonment matter? Routledge. Community Development, 2014.

Vol. 45, No. 2, 121-133, http://dx.doi.org/10.1080/15575330.2014.892019

Morckel, V. (2014) Spatial characteristics of housing abandonment. Applied Geography 48 (2014) 8e16. Elsevier. 
http://journals1.scholarsportal.info.ezproxy.lib.ryerson.ca/pdf/01436228/v48icom plete/8_scoha.xml

Pagano, M. \& Bowman A. (2000) Vacant Land in Cities: An Urban Resource. Centre on Urban \& Metropolitan Policy. The Brookings Institution. December 2000 Survey Series

Province of Ontario (2006) Places to Grow: Growth Plan for the Greater Golden Horseshoe. https://www.placestogrow.ca/index.php?option=com_content\&task=view\&id=9\& $\underline{\text { Itemid }=14}$

Province of Ontario (2008) Community Improvement Planning Handbook. Ministry of Municipal Affairs and Housing. http://www.mah.gov.on.ca/Page1297.aspx

Tappendorf, J. A., \& Denzin, B. O.(2011) Turning vacant properties into community assets through land banking. The Urban Lawyer, 43(3), 801-812

Toronto Financial Services of Toronto (2011) Retrieved from: http://www.tfsa.ca/toronto-advantage/ on July 02, 2014

Wachsmuth, D. (2008) From Abandonment to Affordable Housing: Policy Options for Addressing Toronto's Abandonment Problem. Cities Centre, University of Toronto. 